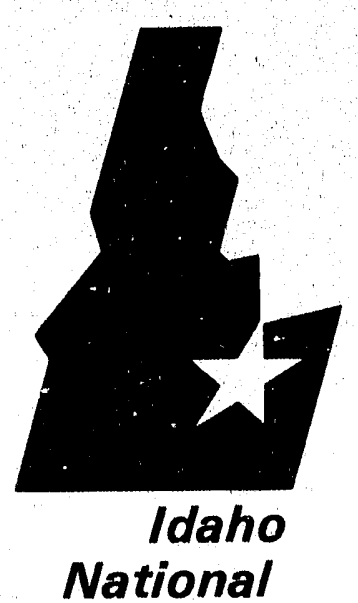

Engineering

Laboratory

\author{
Managed \\ by the U.S. \\ Department \\ of Energy
}

\section{EGG-WTD-9925}

January 1992

\title{
Plasma Treatment of INEL Soll Contaminated with Heavy Metals
}

\author{
B. A. Detering \\ J. A. Batdorf
}

$$
\prod_{S E E R E_{\text {Iaho }}}
$$

Work performed under DOE Contract No. DE-ACO7-761D01570 
This document contains new concepts or the author(s) interpretation of new calculations and/or measurements; accordingly, EG\&G Idaho, Inc. is required by the United States Government to include the following disclaimer:

\section{DISCLAIMER}

This report was prepared as an account of work sponsored by an agency of the United States Government. Neither the United States Government nor any agency thereof, nor any of their employees, makes any warranty, express or implied, or assumes any legal liability or responsibility for the accuracy, completeness, or usefuiness of any information, apparatus, product or process disclosed, or represents that its use would not infringe privately owned rights. Relerences herein to any specific commercial product, process, or service by trade name, trademark. manufacturer, or otherwise, does not necessarily constitute or imply its endorsement, recornmendation, or lavoring by the United States Government or any agency thereot The views and opinions of authors expressed herein do not necessarily state or reflect those of the United States Government or any agency thereot. 


\title{
Plasma Treatment of INEL Soil Contaminated with Heavy Metals
}

\author{
B. A. Detering \\ J. A. Batdorf \\ Published January 1992 \\ Idaho National Engineering Laboratory \\ EG\&G Idaho, Inc. \\ Idaho Falls, Idaho $\mathbf{8 3 4 1 5}$
}

Prepared for the

U.S. Department of Energy

Office of Environmental Restoration and Waste Management

Under DOE Idaho Field Office

Contract DE-AC07-76ID01570

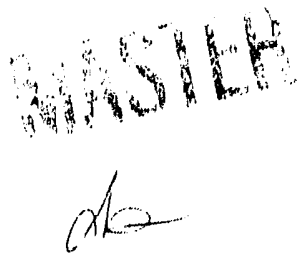


Plasma Treatment of INEL Soil Contaminated with Heavy Metals EGG-WTD-9925

Prepared by:
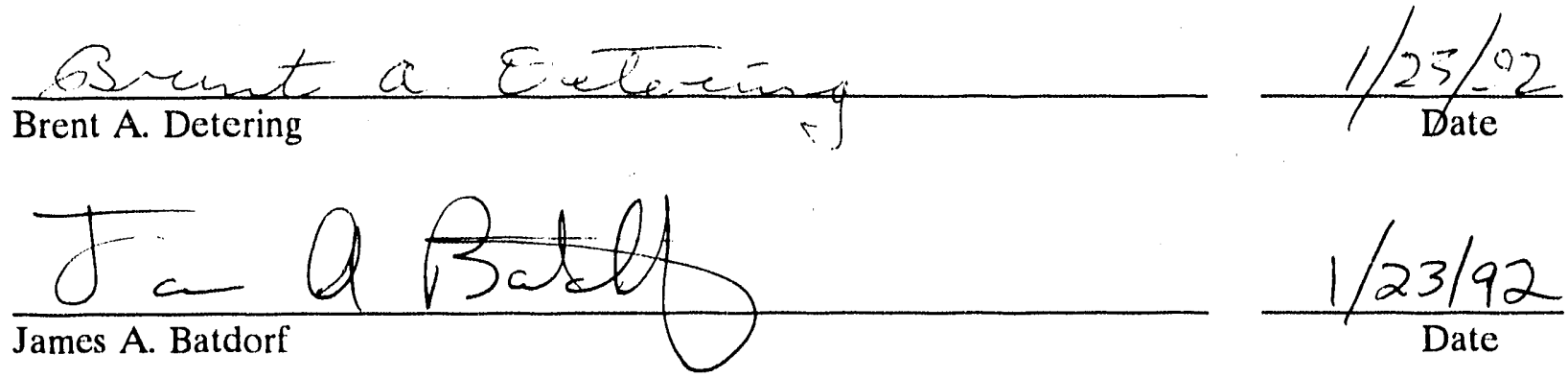

Reviewed and approved by:
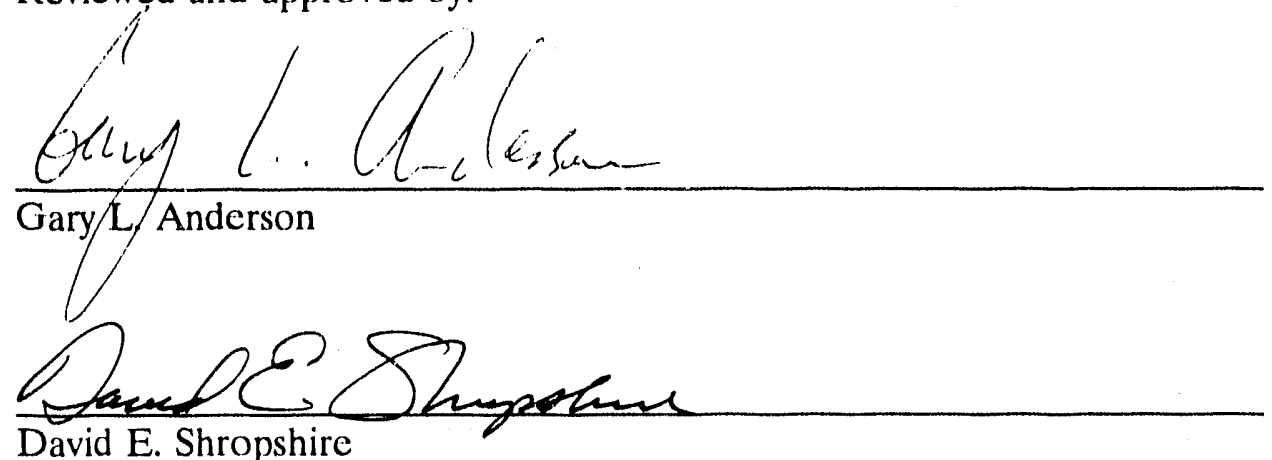

David E. Shropshire
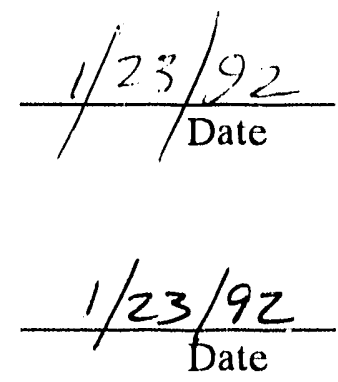

Reviewed by:

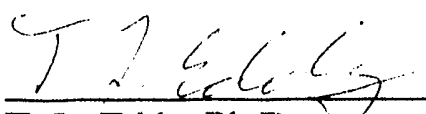

T. L. Eddy, Ph.D.

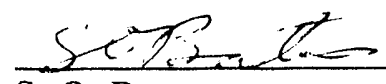

S. O. Bates
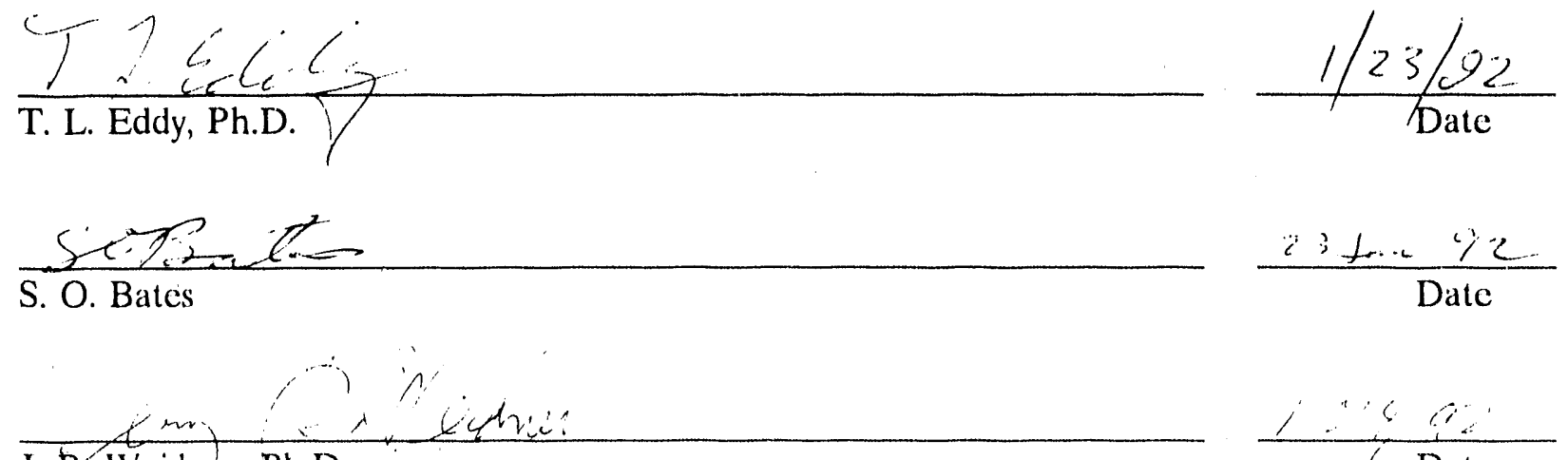

J. R. Weidner, PhD.
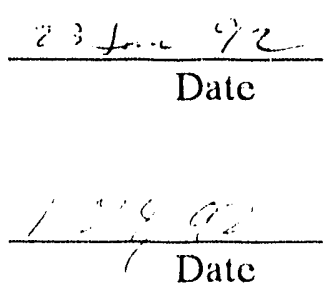


\begin{abstract}
INEL soil spiked with inorganic salts of chromium, lead, mercury, silver, and zinc was melted in a $150 \mathrm{~kW}$ plasma furnace to produce a glassy slag product. This glassy slag is an environmentally safe waste form. In order to reduce the melting ternperature of the soil, sodium carbonate was added to half of the test batches. Random samples from each batch of glassy slag product were analyzed by an independent laboratory for total metals concentration and leachability of metals via the Environmental Protection Agency (EPA) toxicity characterization leaching procedure (TCLP) tests. These tests showed the residual metals were very tightly bound to the slag matrix and were within EPA TCLP limits under these test conditions. Additionally, scanning electron microscopy (SEM) and emissions dispersive spectroscopy (EDS) analysis of the vitrified soil also confirmed that the added metals present in the vitrified soil were totally contained in the crystalline phase as distinct oxide crystallites.
\end{abstract}




\section{ACKNOWLEDGEMENTS}

This report was prepared for the Waste Technology Development Department of EG\&G Idaho, Inc., under contract to the U.S. Department of Energy Idaho Ficld Office, Oftice of Technology Development. Funding was provided under FY-91 Thermal Processing Technologies Technical Task Plan ID-0502-DT, 1991, and ID-040E-2D, 1992. Responsible managers are W. J. Quapp, Group Manager; D. E. Shropshire, Unit Manager; and G. L. Anderson, Principal Investigator.

The authors gratefully acknowledge the assistance of INEL coworkers P. B. Hembree, G. C. Wilson, D. V. Miley, V. L. Smith-Wackerli, A. W. Erickson, P. C. Kong, J. R. Weidner, and T. L. Eddy in the preparation, testing, and analysis of the experiments; W. J. Quapp, G. L. Anderson, S. O. Bates, and J. J. Nelson for technical editing; and J. Dochterman and S. L. "Bud" Camacho for the setup and operation of the plasma system at Plasma Energy Corp.

A preliminary summary of this work was presented at the First INEL Plasma Applications to Waste Treatment Workshop, sponsored by the U.S. Department of Eneigy at the Idaho National Engineering Laboratory, by EG\&G Idaho, Inc., Waste Management Division, Idaho Falls, Idaho, January 16-17, 1991 and at the 43rd Annual Northwest Regional Mecting of the American Chemical Society, Symposium on Chemistry of Mixed Wastes, held in LaGrande, Oregon, June 12-14, 1991. This report contains additional information regarding the materials characterization of the slag samples obtained. 


\section{CONTENTS}

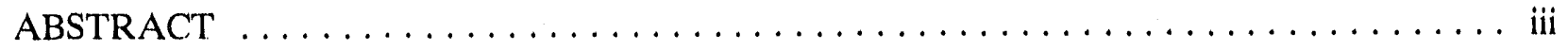

ACKNOWLEDGEMENTS $\ldots \ldots \ldots \ldots \ldots \ldots \ldots \ldots \ldots \ldots \ldots \ldots \ldots \ldots \ldots$

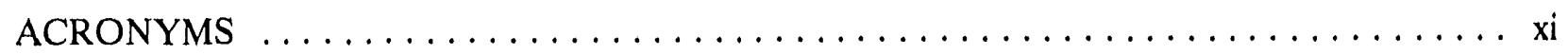

1. INTRODUCTION $\ldots \ldots \ldots \ldots \ldots \ldots \ldots \ldots \ldots \ldots \ldots \ldots \ldots \ldots \ldots$

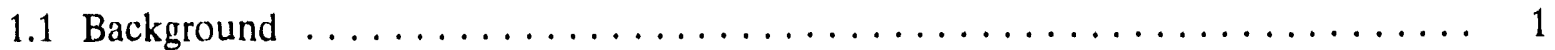

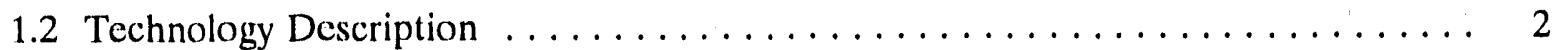

1.3 Plasma Processing of Hazardous and Mixed Wastes $\ldots \ldots \ldots \ldots \ldots \ldots$

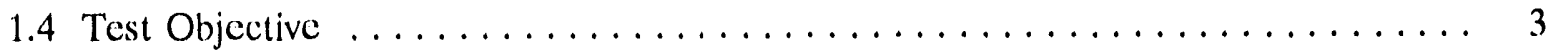

2. EXPERIMENTAL $\ldots \ldots \ldots \ldots \ldots \ldots \ldots \ldots \ldots \ldots \ldots \ldots \ldots$

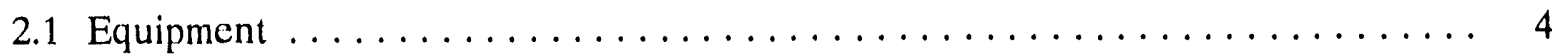

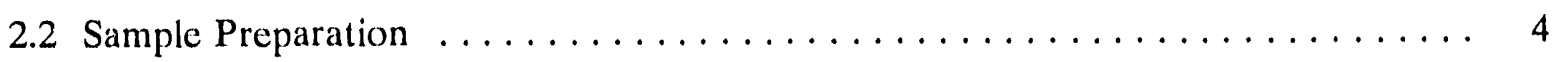

3. RESULTS AND DISCUSSION $\ldots \ldots \ldots \ldots \ldots \ldots \ldots \ldots \ldots \ldots \ldots$

3.1 Energy Requirements of the Melt $\ldots \ldots \ldots \ldots \ldots \ldots \ldots \ldots \ldots \ldots$

3.2 Physical Characteristics of the Vitrified Soil $\ldots \ldots \ldots \ldots \ldots \ldots \ldots \ldots \ldots \ldots$

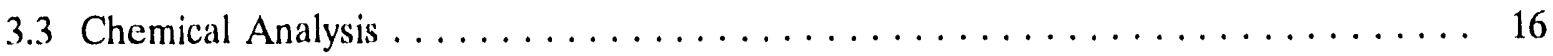

3.4 Microstructure and Phase Composition of the Vitrified Soil $\ldots \ldots \ldots \ldots \ldots \ldots$

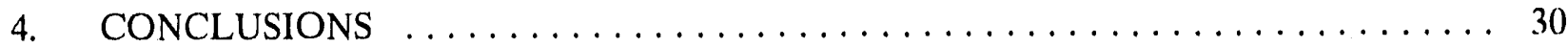

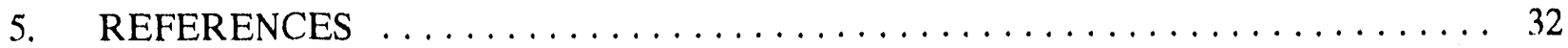




\section{FIGURES}

1. Plasma Energy Corp. Plasma Tilt Furnace used in these experiments $\ldots \ldots \ldots \ldots \ldots$

2. Photograph of viscous slag poured at $1248^{\circ} \mathrm{C} \ldots \ldots \ldots \ldots \ldots \ldots \ldots \ldots$

3. Photograph of fluid slag poured at $1550^{\circ} \mathrm{C} \ldots \ldots \ldots \ldots \ldots \ldots \ldots \ldots$. $\ldots \ldots \ldots$

4. Photograph of slag after pouring onto sand $\ldots \ldots \ldots \ldots \ldots \ldots \ldots \ldots \ldots \ldots$

5. Average power used to melt each batch of soil $\ldots \ldots \ldots \ldots \ldots \ldots \ldots \ldots \ldots$

6. Gross and net energy per kilogram of soil used during each batch melt . . . . . . . 14

7. Photograph of tilt furnace with top half removed after test showing erosion of

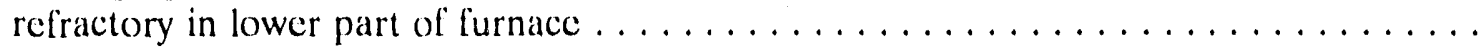

8. SEM photograph of slag sample PEC B-4 showing the variety of colored streaks that occur in different regions of the sample $\ldots \ldots \ldots \ldots \ldots \ldots \ldots \ldots$

9. SEM photographs of vitrified soil in slag sample PEC A-1 showing microstructure at (a) 50X showing the large amount of amorphous glass, (b) 500X showing the blocky crystals, and (c) 1000X showing the dendrite details. The composition for EDS sports sampled is given in Table $7 \ldots \ldots \ldots \ldots \ldots \ldots \ldots \ldots \ldots \ldots$

10. SEM photographs of vitrified soil in slag sample PEC A-2 showing microstructure at (a) $50 \mathrm{X}$ showing the predominantly amorphous glass phase and small size of the crystals and (b) $1000 \mathrm{X}$ showing the blocky dendritic phases. . . . . . . . . . .

11. SEM photographs of vitrified soil in slag sample PEC A-3 showing microstructure at (a) 50X showing a streaky set of small crystals in the predominantly glass phase and (b) $500 \mathrm{X}$ showing the various crystalline structure $\ldots \ldots \ldots \ldots \ldots \ldots$

12. SEM photographs of vitrified soil in slag sample PEC A-4 showing at (a) 50X showing the extremely small crystals in the predominantly amorphous glass phase and (b) $1000 \mathrm{X}$ showing the needle shaped and dendritic crystals

13. SEM photographs of vitrified soil microstructure in sample PEC B-1 at (a) 50X showing crystal groups in the predominantly amorphous glass phase and

(b) $1000 \mathrm{X}$ showing the blocky, small, dendritic shaped crystals . . . . . . . . . . . .

14. SEM photographs of vitrified soil microstructure in sample PEC B-2 at (a) 50X showing the predominantly amorphous phase from the rapid cooling and

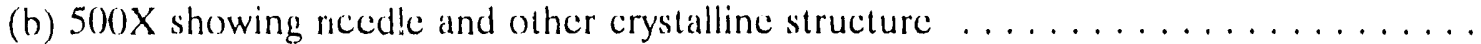

15. SEM photographs of vitrified soil microstructure in sample PEC i 3

(a) 50X showing some crystal groups and the predominantly amorphous glass phase from the rapid cooling and (b) 100)(X showing the streaky

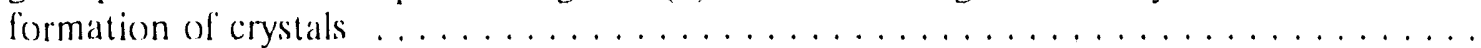


16. SEM photographs of vitrified soil in sample PEC B-4 at (a) $50 \mathrm{X}$ showing a different type of microstructure and (b) 500X showing a mixture of needles, blocky, small, and dendritic crystals .

\section{TABLES}

1. INEL soil sample analyses $\ldots \ldots \ldots \ldots \ldots \ldots \ldots \ldots \ldots \ldots \ldots \ldots \ldots \ldots \ldots \ldots$

2. Metal compounds and concentrations in waste analog $\ldots \ldots \ldots \ldots \ldots$

3. Metallic compounds used to produce waste analog $\ldots \ldots \ldots \ldots \ldots \ldots$

4. Summary of energy input, material feed and recovery $\ldots \ldots \ldots \ldots \ldots \ldots$

5. Concentrations of metals in vitrified soil $\ldots \ldots \ldots \ldots \ldots \ldots \ldots \ldots \ldots$

6. Results of toxicity characteristic leachate procedure (TCLP) tests $\ldots \ldots \ldots \ldots$

7. PEC series slag composition via standardless EDS analysis . . . . . . . . . . 29 


\section{ACRONYMS}

API average power input

CERCLA Comprehensive Environmental Response, Compensation, and Liability Act

COCA Compliance Order and Consent Agreement

DOE Department of Energy

EAF electric arc furnace

EDS emissions dispersive spectroscopy

EPA Environmental Protection Agency

ICr inductively coupled plasma

INEL Idaho National Engineering Laboratory

PAFE plasma arc furnace experiment

PEC Plasma Energy Corporation

RWMC Radioactive Waste Management Complex

SDA Subsurface Disposal Area

SEM scanning electron microscopy

TCLP toxicity charactcrization leaching procerture

TRA Test Reactor Area

XRF $\quad \mathrm{x}$-ray florescence 


\section{Plasma Treatment of INEL Soil \\ Contaminated with Heavy Metals}

\section{INTRODUCTION}

The studies described in this report were conducted to determine the applicability of thermal plasma technology for vitrification of soil and stabilization of heavy metal contaminates in the vitrified matrix. Thermal plasmas provide the high energy heat flux necessary to melt the high-temperature basaltic soils present at the Idaho National Engineering Laboratory (INEL). The high heat flux produced by a plasma would allow a soil vitrification process to be operated continuously. Specific topics addressed in this report are: the effect of adding flux material to the melt to lower the melting point of the soil, partitioning of metals between slag and off-gas, leachability of metals from the vitrified soil, and the composition in the phases found in the vitrified soil.

\subsection{Background}

From the advent of nuclear weapons, the Department of Energy (DOE) has disposed of nuclear wastes produced by nuclear weapons facilities at several disposal sites around the U.S. Disposal methods for non-fuel cycle wastes consisted primarily of subsurface land burial. An estimated $65,800 \mathrm{~m}^{3}$ of radioactive wastes were stored in this manner at the INEL Radioactive Waste Management Complex (RWMC) Subsurface Disposal Area (SDA) between 1954 and 1970. ${ }^{1}$ In addition, approximately $283,0(0) \mathrm{m}^{3}$ of soil used as underburden and overburden in the disposal process is potentially contaminated.

The INEL was added to the Environmental Protection Agency's (EPA) National Priorities List in 1989. This action has prompted the DOE to begin developing plans under the Comprehensive Environmental Response, Compensation, and Liability Act (CERCLA) to accomplish remediation of wastes at the INEL including those buried at the SDA. One possible type of remediation will necessarily include methods for retrieval and treatment to produce an acceptable waste form that can be stored at a permanent disposal site. $^{2}$

Several trechnologies are currently being evaluated as to their applicability to processing radioactive wastes. $2,3,4$ A viable process should result in a waste form that is low in organic content, immobilizes inorganics, and reduces volume. One of the more promising technologies is high temperature thermal plasmas. However, this is still an emerging technology which has not been demonstrated on an industrial scale. ${ }^{5}$ 


\subsection{Technology Description}

A plasma is a highly ionized gas, occasionally referred to as the "fourth" state of matter, because it exhibits propertics of both liquids and gases. Plasmas can be generated by a variety of techniques and occur over a wide range of pressures and energy levels. For the purposes of this report, the term "plasma" will be limited to plasmas at atmospheric pressure and temperatures from $5,000)$ to $20,000 \mathrm{~K}$, and generated by eiectric discharges. Materials processing systems using plasmas have certain advantages over other thermal processing techniques. ${ }^{6,7,8}$ These advantages are:

- High temperature and energy density

- Complete control over chemical reaction conditions (i.e., oxidizing, reducing, or inert)

- Low gas throughput for easicr/cheaper off-gas cleanup

- High temperature, high energy density, and low gas throughput result in smaller size production unit and lower capital cost.

Plasma systems have been used for a variety of materials processes. In the metallurgical industry, plasma processes have been developed for the production of ferrochromium, ferromanganese, and ferrovanadium by the carbothermic reduction of their respective oxide ores." Plasma systems have also been used for the recovery of metals from electric are furnace (EAF) dusts. In this process chromium, iron, and nickel remain in the melt and are easily separated from the slag. Volatile metals, such as cadmium, zinc, and lead, are entrained in the off-gas, collected in a bag house, and used as lecdstock for zine production. ${ }^{10}$ A survey of companies developing plasma systems for processing solid hazardous waste are presented elsewhere. ${ }^{11-15}$

Plasma vitrification of waste materials is a straight-forward process. Solid material added to the reactor in an oxidizing atmosphere is melted, available metals form metal oxides, and then dissolve into the sitica/alumina matrix. Input electrical power and material feed rate control the plasma temperature and off-gas temperature at the exit port. Volatile substances in the slag will be transported into the gas phase; control of the slag temperature and chemistry can affect the volatility of some metals. At the high temperatures obtained in the plasma region, complex molecules are completely decomposed. Even diatomic molecules decompose it the residene time is sufficiently long. Gaseous product composition is dominated by chemical reaction kinctics in the quench region. Additional gases can be added to the plasma gases exiting the reactor to increase or decrease the amount of oxygen, promote a particular reaction, or quench the hot exiting gatses to a lower temperalure. 


\subsection{Plasma Processing of Hazardous and Mixed Wastes}

Plasma processing provides a neans of treating soil contaminated with hazardous organic compounds, toxic metals, radioactive isotopes, and combustibles. Potentially this treatment can provide volume reduction, clean off-gas, and non-leachable glassy slag. This treatment has some similarities with incineration, but is significantly different in many aspects. Plasma treatment allows the use of high temperatures with low gas volumes and high oxygen partial pressure. This enhances organic destruction while decreasing off-gas cleaning costs. Plasma treatment also results in a solid glassy or rock-like slag product in which toxic metals and radioactive isotopes are chemically part of or in solution with the host slag. This fully oxidized slag is leach resistant and a highly stable waste form.

Plasma processing is applicable to a variety of DOE and INEL wastes and can be implemented with several equipment configurations. This test examines one type of waste and one plasma reactor configuration. The waste analog, INEL soil contaminated with heavy metals, is representative of INEL Compliance Order and Consent Agreement (COCA) wastes ${ }^{16-18}$ at the Test Reactor Area (TRA). These wastes consist of soil contaminated with small quantities of organics, inorganics, and radioisotopes. ${ }^{19}$ Due to the low concentrations of hazardous and radioactive waste components and advantages of onsite remediation, COCA wastes would be an ideal subject on which to perform a plasma remediation demonstration test.

\subsection{Test Objective}

The primary objective of this test was to examine the feasibility of a plasma process to stabilize INEL soil contaminated with heavy metals in a glassy slag matrix. A secondary objective was to determine the partitioning of metals with varying volatility between slag and gas phases. Data provided by these tests will be useful in designing further tests and compliment tests being conducted on the RETECH plasma centrifugal reactor system, ${ }^{20}$ located at Mountain States Energy Corporation's facility in Butte, Montana.

Due to the costs of extensive off-gas sampling, organic compound destruction was not studied in these tests. 


\section{EXPERIMENTAL}

\subsection{Equipment}

Batch melting tests were performed at Plasma Energy Corporation's plasma test facility in Raleigh, North Carolina. A $150 \mathrm{~kW}$ nontransferred plasma torch ${ }^{21}$ was installed in a refractoryinsulated tilt furnace (sec Figure 1). Soil was fed into the reactor using a vibrating screw feeder. System off-gas was processed through a wet scrubber and bag house before release to the atmosphere. Upon completion of each batch melt, the furnace was rotated on its axis to pour the molted material onto a sand bed for cooling.

\subsection{Sample Preparation}

The soil used in these tests was collected onsite at the INEL south of the RWMC and is typical of surface soil throughout the INEL. INEL soil has been characterized in several studies and a single sample was used to characterize the starting material. Table 1 shows analysis results obtained from soil used in this test and the results of two previous INEL soil analyses.

A waste analog was prepared from a mixture of INEL soil and metal nitrate salts. Metals content added to the soil used in these tests (see Table 2) approximate worst-case results from analysis of the TRA Warm Waste Pond and TRA paint ditch (INEL COCA sites). COCA wastes are also very high in sulfate content, but no sulfate salts were added to the waste analog to avoid problems associated with sulfur dioxide off-gas in these tests.

Soil test batches were prepared at the INEL for plasma melting by first collecting a bulk soil sample (50) kg) and drying it to less the $5 \%$ moisture content. The dried soil was then split into two parts of $200 \mathrm{~kg}$ each. Each $200 \mathrm{~kg}$ batch was then divided into five $40 \mathrm{~kg}$ batches. Metal nitrate salts were then added to each batch in the amounts shown in Table 3. The lirst set of test batches (A Batches) was not altered further. The expected slag viseosity of the second set of five samples (B Batches) was reduced by adding sodium carbonate to provide a $5 \%$ increase in the sodium monoxide content of the slag according to Reaction 1 as follows:

$\mathrm{Na}_{2} \mathrm{CO}_{3}-\ldots>\mathrm{Na}_{2} \mathrm{O}+\mathrm{CO}_{2}$

Prepared soil was then shipped from the INEL (o) Plasma Energy Corporation for processing.

Molten slag from each batch was poured, conled, weighed, and repackaged for return to the INEL for further analysis. 


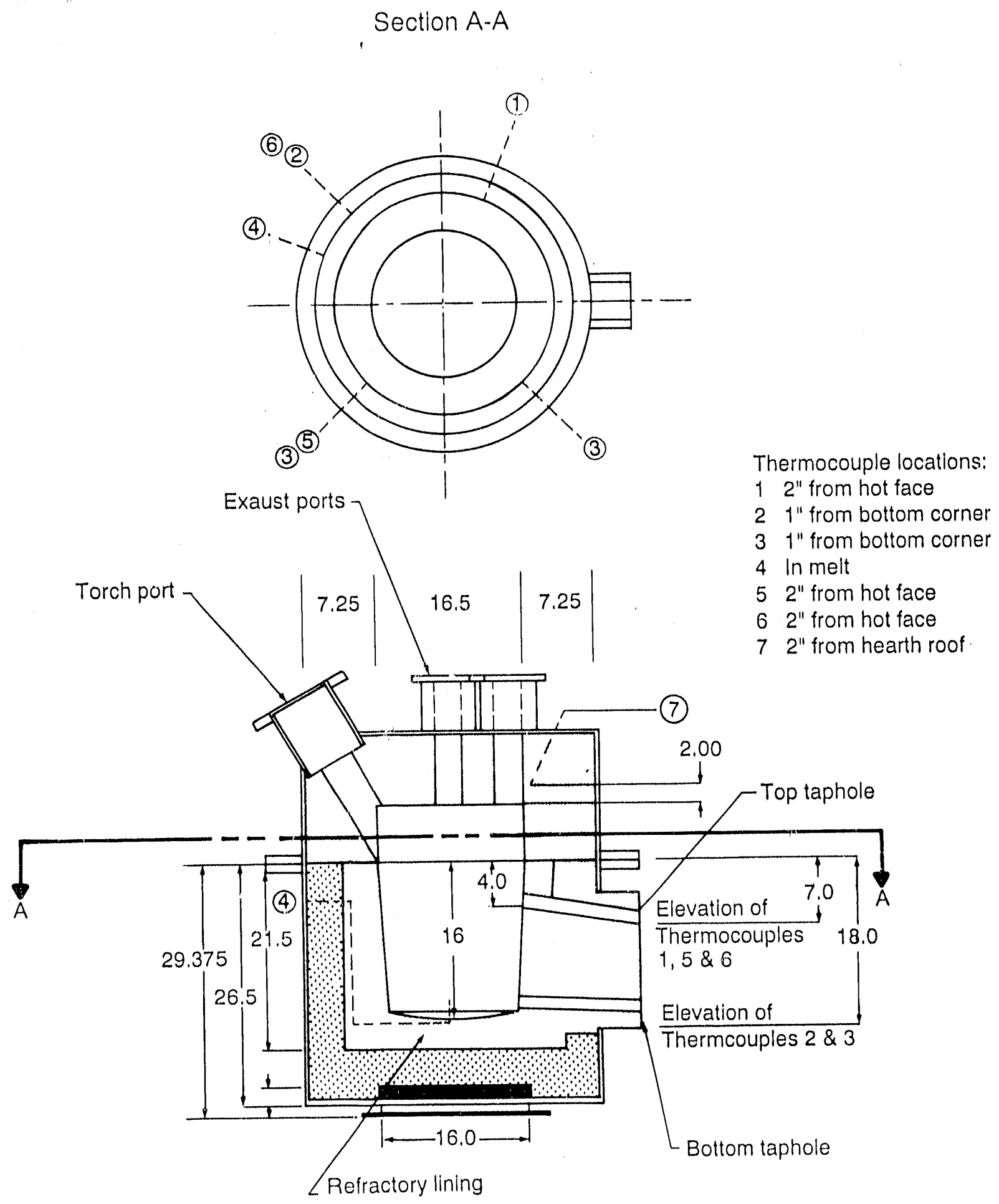

FN 8021-001

Tilt-Furnace Design

Figure 1. Plasma Energy Corp. Plasma Tilt Furnace used in these experiments. 
Table 1. INEL soil sample analyses.

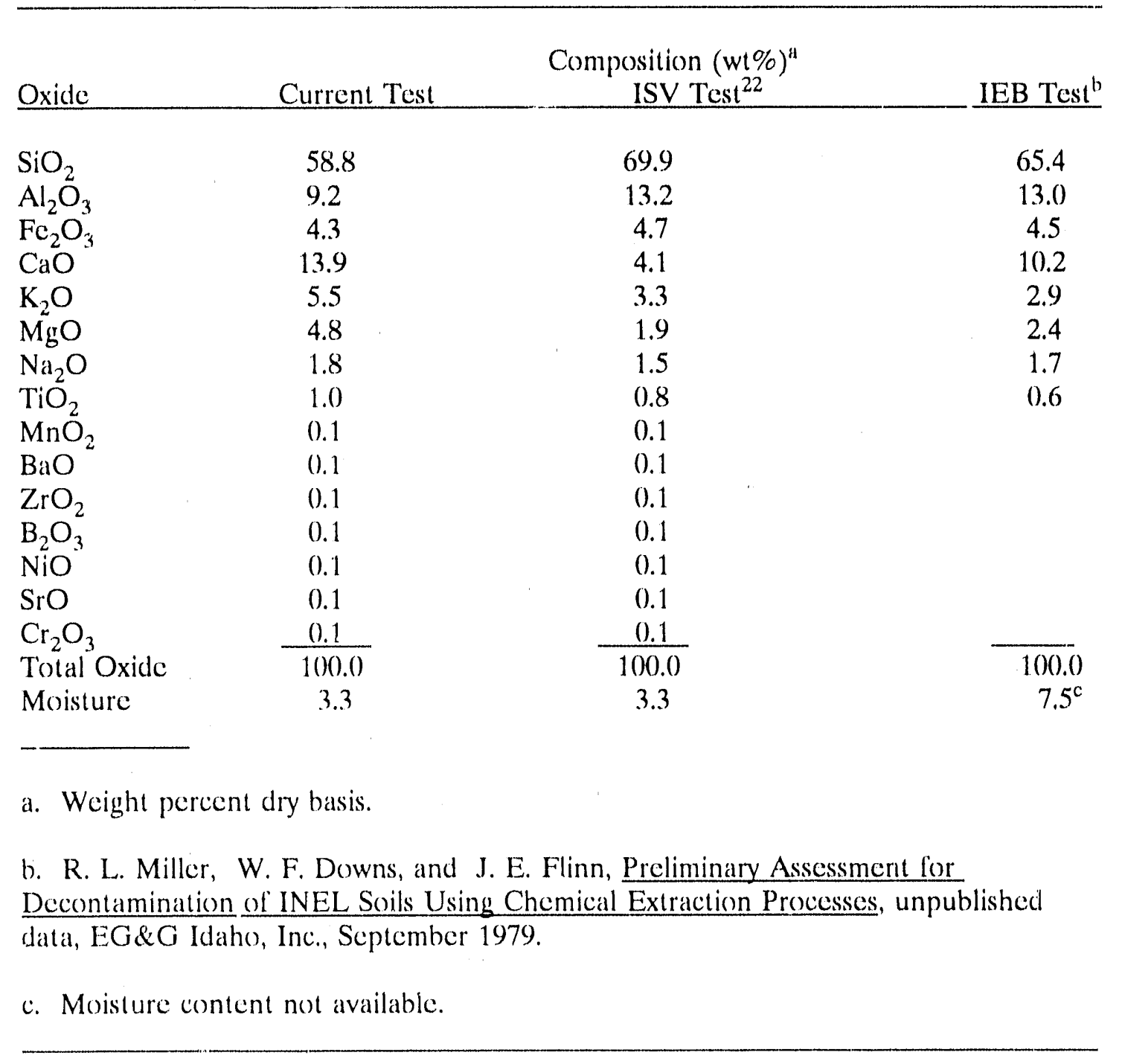

Table 2. Metal compounds and concentrations in waste analog.

\begin{tabular}{lc}
\hline Mctal & Concentration \\
\hline Chromium & $4000 \mathrm{ppm}$ \\
Lead & $2400 \mathrm{ppm}$ \\
Mercury & $40 \mathrm{ppm}$ \\
Silver & $20 \mathrm{ppm}$ \\
Zinc & $18(0) \mathrm{ppm}$ \\
\hline
\end{tabular}


Table 3. Metallic compounds used to produce waste analog.

\begin{tabular}{ll}
\hline Compound & Quantity Added per 100 kg Soil \\
\hline Chromium Nitrate & $3.66 \mathrm{~kg}\left(50 \% \mathrm{Cr}\left(1 \mathrm{NO}_{3}\right)_{3} \mathrm{Soln}.\right)$ \\
Lead Nitrate & $0.384 \mathrm{~kg} \mathrm{~Pb}\left(\mathrm{NO}_{3}\right)_{2}$ \\
Mercury Nitrate & $0.00683 \mathrm{~kg} \mathrm{Hg}\left(\mathrm{NC}_{3}\right)_{2} \cdot \mathrm{H}_{2} \mathrm{O}$ \\
Silver Nitrate & $0.00315 \mathrm{~kg} \mathrm{AgNO} / 3$ \\
Zinc Nitrate & $0.819 \mathrm{~kg} \mathrm{Zn}\left(\mathrm{NO}_{3}\right)_{2}$ \\
Sodium Carbonate & $8.5 \mathrm{~kg} \mathrm{Na} \mathrm{CO}_{3}$
\end{tabular}

a. Added to Batun No. B-1 to B-5 only. 


\section{RESULTS AND DISCUSSION}

\subsection{Energy Requirements of the Melt}

Energy requirements to maintain the furnace interior refractory between 1200 and $16(0) 0^{\circ} \mathrm{C}$ were determined during the refractory cure and preheat period prior to testing. New furnace refractory was cured over a period of 4 days prior to commencing melt tests. Green furnace refractory was molded into place, furnace assembled, and interior refractory temperature slowly brought up to 150() to 160()$^{\circ} \mathrm{C}$. Significant plasma furnace operating conditions during these tests are given in Table 4.

Five melts of INEL soil, with no flux added (Batches A1-A5), were completed on the first day of testing. The first three batches were processed by feeding the soil into the furnace over a period of 30 to 80 minutes, waiting for the melt to reach temperature, then tapping. Batch A-1 was tapped at a slag temperature of $1145^{\circ} \mathrm{C}$. At this low temperature the slag was too viscous to pour readily (sec Figure 2). Before Batch A-2 was processed, the furnace was then preheated for 20 minutes to raise the interior furnace temperature. Batches $\mathrm{A} 2$ through $\mathrm{A} 5$ were tapped at slag temperatures above 15()$)^{\circ} \mathrm{C}$ (sec Figure 3).

The last two batches were held above $1500^{\circ} \mathrm{C}$ for 30 minutes after material feeding was complete, then tapped. Figure 4 is representative of the appearance of typical cooled slag. Gross energy requirements for the first live batches ranged from 3.55 to $8.71 .0 \mathrm{~kW} / \mathrm{kg}$ (Av. $6.24 \mathrm{~kW} / \mathrm{kg}$ ). Due to low initial furnace temperature, Batch A1 required additional heat to allow tapping of the highly viscous slag. When furnace losses are accounted for, net energy requirements for melting the soil and maintaining the temperature of the meit ranged between 1.13 and $2.13 \mathrm{~kW} / \mathrm{kg}$ (Av. $1.64 \mathrm{~kW} / \mathrm{kg}$ ).

The linal live melts (B-1 to B-5) containing sodium carbonate flux were completed on the siceond day of testing. The first three batches were tapped as soon as the melt became fluid enough 10 lap after material leed was complete. A visual test of the viscosity was aceomplished when slag 1 emperature was measured using a dipstick thermocouple. Slag viseosity was deemed low enough to pour when the slag readily dripped off the dipstick as it was withdrawn from the furnace.

Batches $B 1$ through $B .3$ had an average gross energy requirement of $6.52 \mathrm{~kW} / \mathrm{kg}$ and average net energy requirement of $2.04 \mathrm{~kW} / \mathrm{kg}$. The observed increase in energy required was due to the malfunction of the powder feeder on Batch B2 which nearly doubled the time required to feed the material into the furnace. When the energy requirements of Batch B-2 are excluded, the average gross and net power requirements of Batches $B 1$ and $B .3$ are 5.47 and $1.76 \mathrm{~kW} / \mathrm{kg}$, respectively.

The final two melts were aceomplished with a 30-minute hold time following completion of material leed. Gross and net energy requirements for these two batches were 9.58 and $3.29 \mathrm{~kW} / \mathrm{kg}$, 
Table 4. Summary of encrgy input, material f'eed, and recovery.

\begin{tabular}{|c|c|c|c|c|c|c|c|c|c|c|}
\hline Batch\# & $\mathrm{A} 1$ & $\Lambda 2$ & $\mathrm{~A} 3$ & $\Lambda 4$ & AS & B1 & 132 & 133 & 134 & 13.5 \\
\hline $\begin{array}{l}\text { APl } \\
k W\end{array}$ & 171.7 & 196.4 & 195.7 & 195.5 & 183.8 & 194.6 & 204.3 & 204.6 & 192.8 & 201.6 \\
\hline $\begin{array}{l}\text { 'TO'IAI } \\
\text { POWER. } \\
\mathrm{kW} / \mathrm{kg}\end{array}$ & 8.71 & 3.55 & 6.90 & 5.87 & 6.19 & 5.72 & 8.61 & 5.22 & 9.64 & 9.53 \\
\hline $\begin{array}{l}\text { NI:'T } \\
\text { POWIER } \\
\text { kW'kg }\end{array}$ & 1.91 & 1.13 & 2.13 & 1.71 & 1.33 & 1.64 & 2.59 & 1.88 & 3.10 & 3,48 \\
\hline $\begin{array}{l}\text { POUR } \\
\text { TEMP }\end{array}$ & 1145 & 1578 & 1540 & 1660 & 1578 & 1373 & 1434 & 13.54 & 1377 & 1338 \\
\hline $\begin{array}{l}\text { FLED } \\
\text { TIME } \\
\text { min. }\end{array}$ & 81.0 & 29.3 & 55.4 & 72.1 & 80.1 & 53.6 & 76.5 & 47.0 & 91.3 & 86.6 \\
\hline $\begin{array}{l}\text { HOLD } \\
\text { TIMI: } \\
\text { min. }\end{array}$ & 0 & 0 & 0 & 30 & 30 & 0 & 0 & 0 & 30) & 30 \\
\hline $\begin{array}{l}\text { IEEED } \\
\text { RATE } \\
\mathrm{kg} / \mathrm{hr}\end{array}$ & 19.7 & 55.2 & 28.3 & 33,3 & 29.7 & 34.0 & 23.7 & 39.1 & 20.0 & 21.1 \\
\hline $\begin{array}{l}w 1 / k g \\
\text { IEELED }\end{array}$ & 26.61 & 26.97 & 26.19 & 40.02 & 39.60 & 30.41 & 30.24 & 30.62 & 30.44 & 30.52 \\
\hline $\begin{array}{l}\text { wt/kg } \\
\mathrm{RECOOV}\end{array}$ & 15.47 & 21.82 & 23.50 & 35.42 & 34.79 & 21.73 & 22.54 & 22.91 & 28.39 & 27.08 \\
\hline $\begin{array}{l}\% w 1 \\
\text { L.OSS }\end{array}$ & 41.9 & 19.1 & 10.3 & 11.5 & 12.1 & 28.5 & 25.5 & 25.2 & 6.7 & 11.3 \\
\hline
\end{tabular}




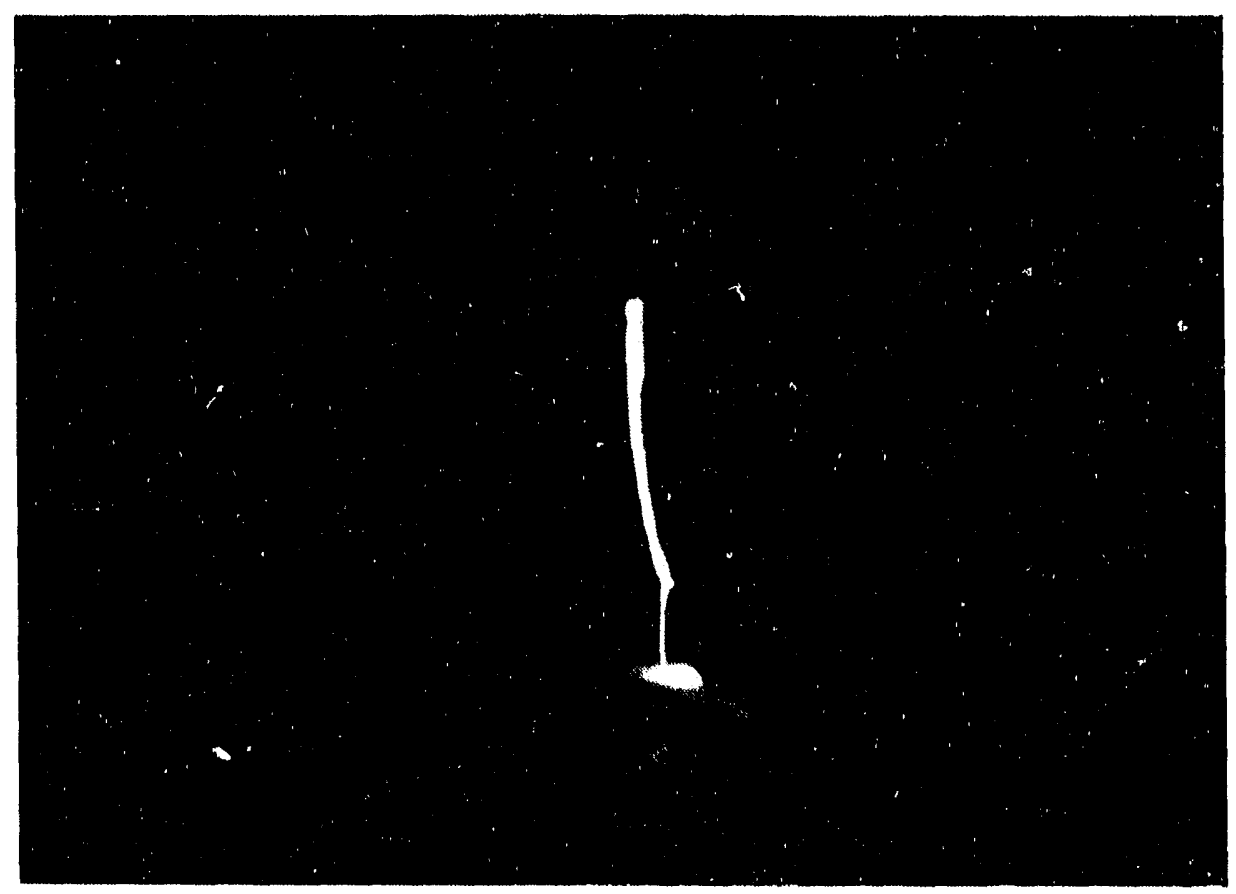

Figure 2. Photograph of viscous slag poured at $1248^{\circ} \mathrm{C}$.

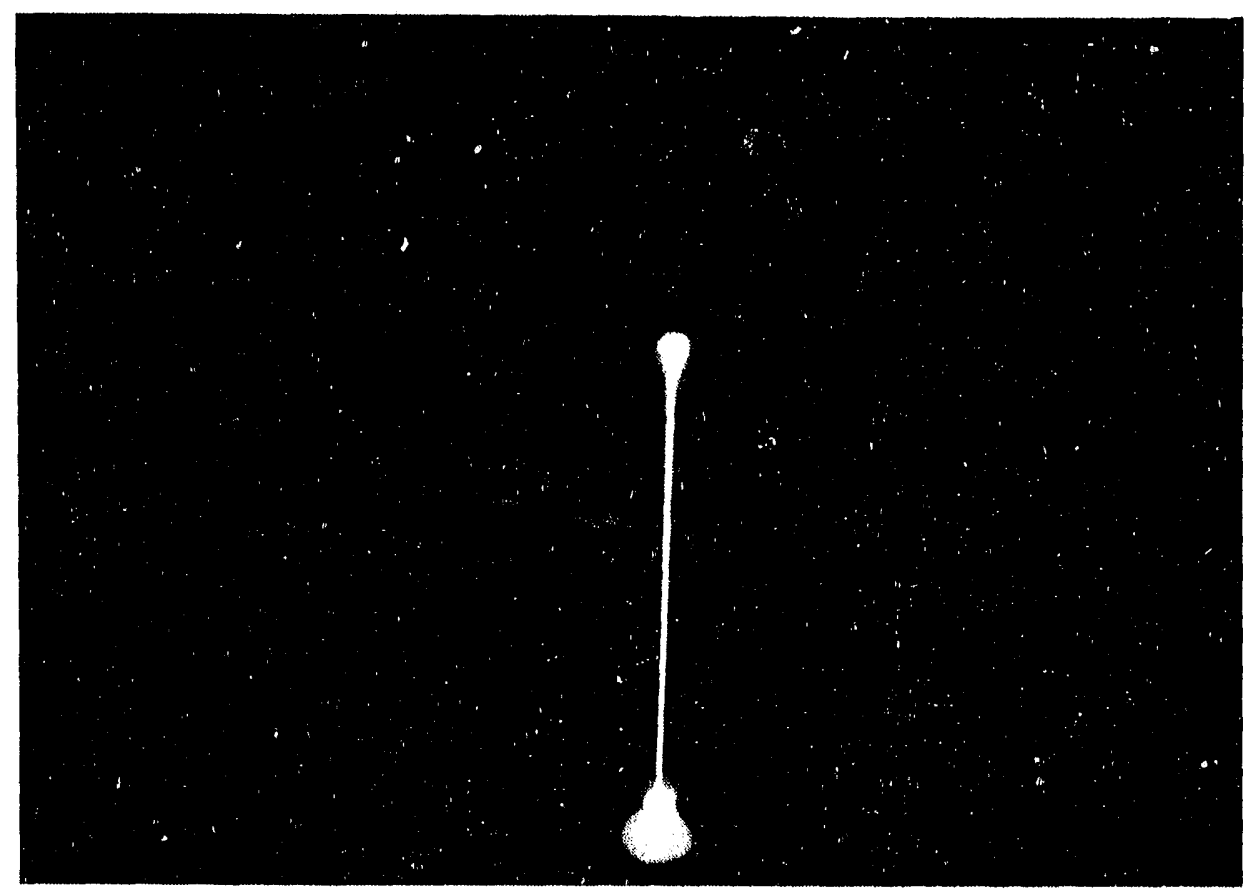

Figure 3. Photograph of fluid slag poured at $1550^{\circ} \mathrm{C}$. 


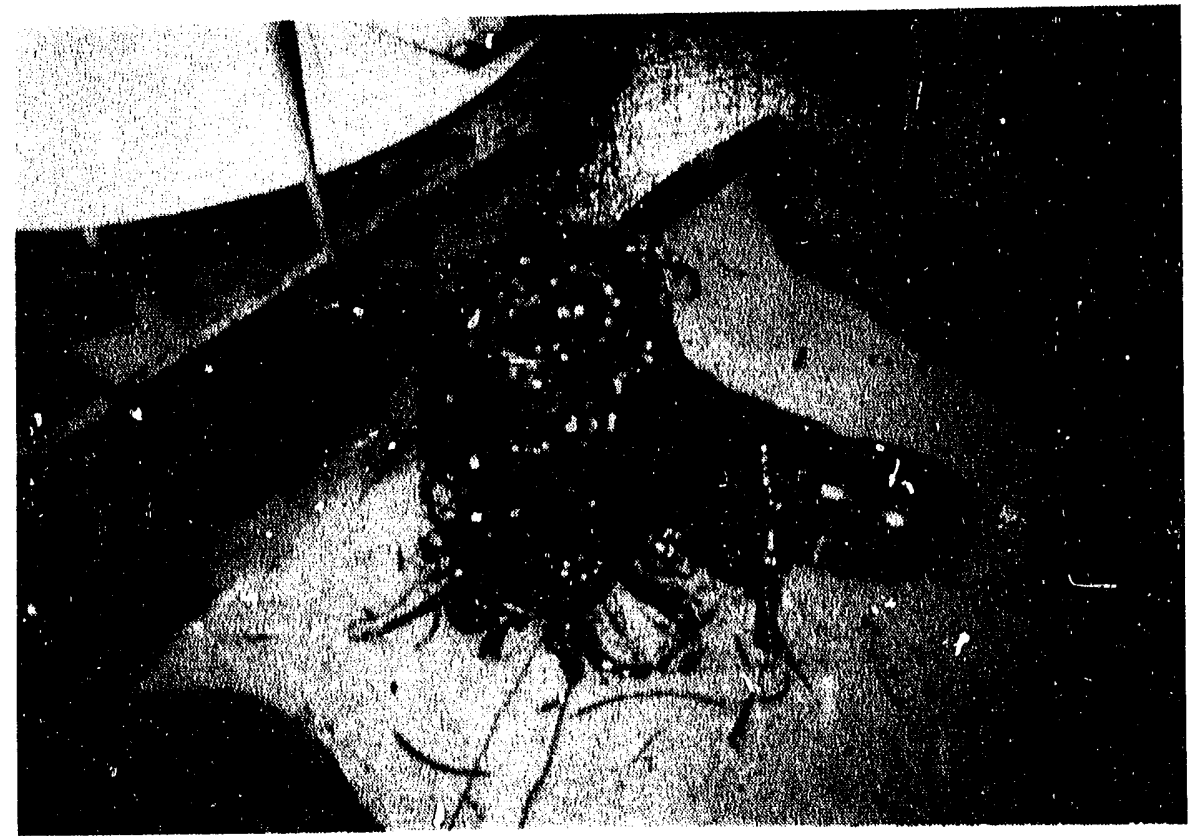

Figure 4. Photograph of slag after pouring onto sand. 
respectively. The increase in energy requirements for these batches was due to crosion of the refractory furnace lining and increased heat losses to the furnace exterior.

Average power input to the plasma furnace per batch are shown in Table 4 and summarized in Figure 5. Average power input (API) is calculated as the amount of electrical energy input to the plasma torch minus heat losses to the torch eooling water and averaged over the time of the experiment. Batches A1 to A5 had an API of $188.6 \mathrm{~kW}$ and Batches B1 to B5 had an API of 199.6 $\mathrm{kW}$. The increase in API for the B batches may have been due to the crosion of the furnace refractory by the sodium carbonate flux.

Total and net energy requirements per pound of feed material for each melt are tabulated in Table 4 and summarized in Figure 6. Again, average total and net power inputs to the melt were higher for the melts containing flux.

Melts containing the sodium carbonate lluxing agent resulted in an average pour (tap) temperature of about $200^{\circ} \mathrm{C}$ less than the melts containing no flux. However, due to an apparent reaction between the sodium carbonate flux and the refractory lining in the furnace, lower tapping temperature of the melt was not reflected in lower energy requirements. Erosion damage to the refractory lining of the furnace can be seen in Figure 7. In Figure 7, the top half of the plasma furnace has been removed and the steel shell of the furnace and the inner refractory lining can be seen. The light colored areas are from a ceramic gasket used between the two halves of the furnace. The croded area of refractory appears as an indentation near the top of the refractory lining. In addition to the eroded area seen in Figure 7, the inside diameter of the refractory lining increased from $40 \mathrm{~cm} \mathrm{to} \approx 50 \mathrm{~cm}$.

Average weight loss for the A and B batches was $17.8 \%(5.68 \mathrm{~kg})$ and $19.5 \%(5.91 \mathrm{~kg}) \mathrm{per}$ batch, respectively. This weight loss can be accounted for as water loss /ca. 3.3\% from soil and ca. $5.7 \%$ from $50 \mathrm{Cr}\left(\mathrm{NO}_{3}\right)$ ); volatilization of metal nitrates as metal vapor, metal oxide fincs, and $\mathrm{NO}_{\mathrm{X}}$ (ca. 10 wt \%); carry over of soil fines in the off-gas; and for B batches, off-gassing of carbon dioxide (ca. $7 \mathrm{wt} \%$, Reaction 1).

\subsection{Physical Characteristics of the Vitrified Soil}

Vitrified soil as poured on a sand mold had a shiny glass-like surface as shown in Figure 4. During the period of rapid cooling following tapping, the material could be broken up quite casily with a hammer. After cooling was complete, the material was much harder to break. Density of vitrified samples ranged from 2.43 to $2.65 \mathrm{~g} / \mathrm{cm}^{3}$. 


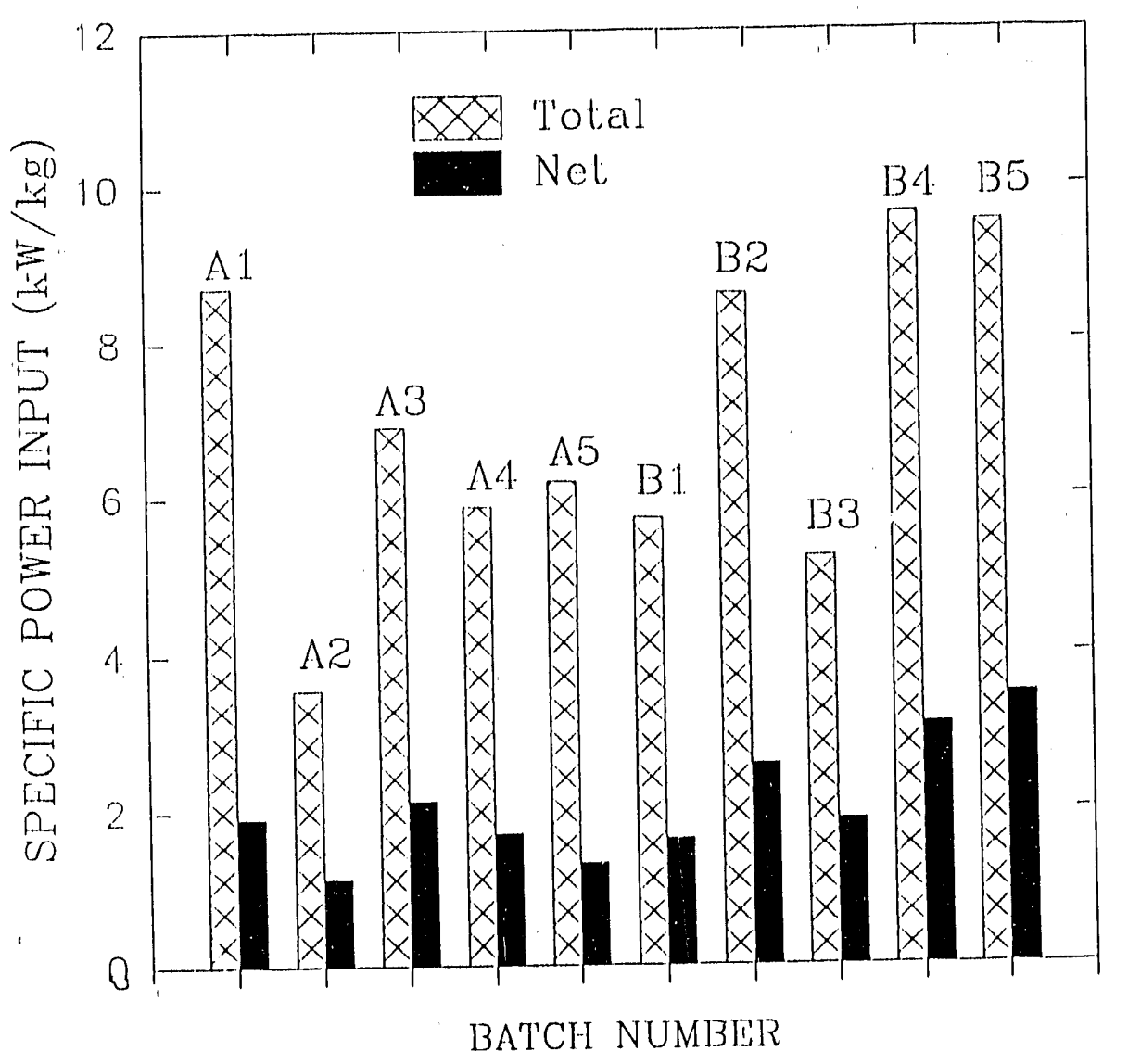

Figure 5. Average power used to melt each batch of soil. 


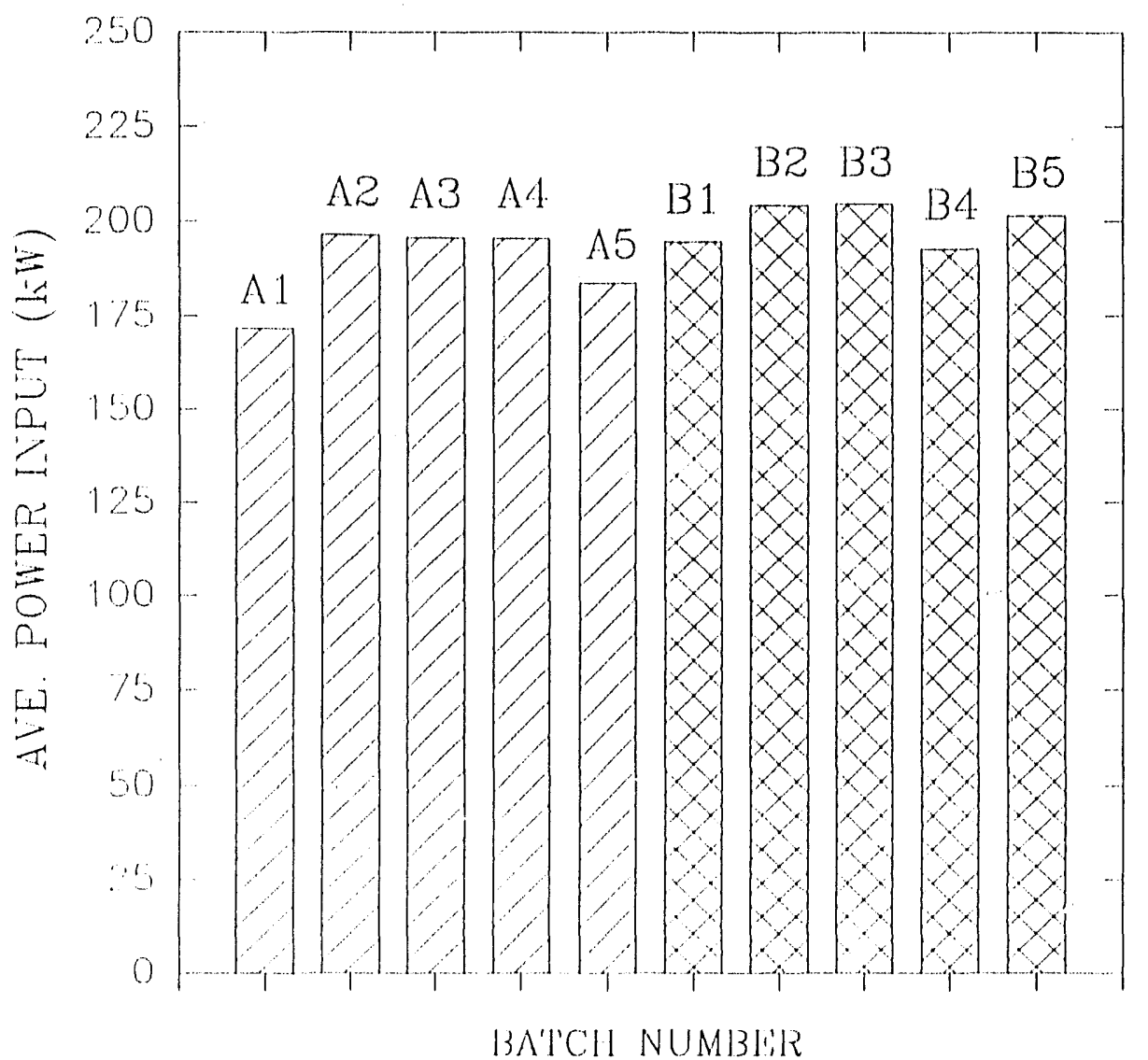

Figure 6. Gross and net energy per kilogram of soil used during each batch melt. 


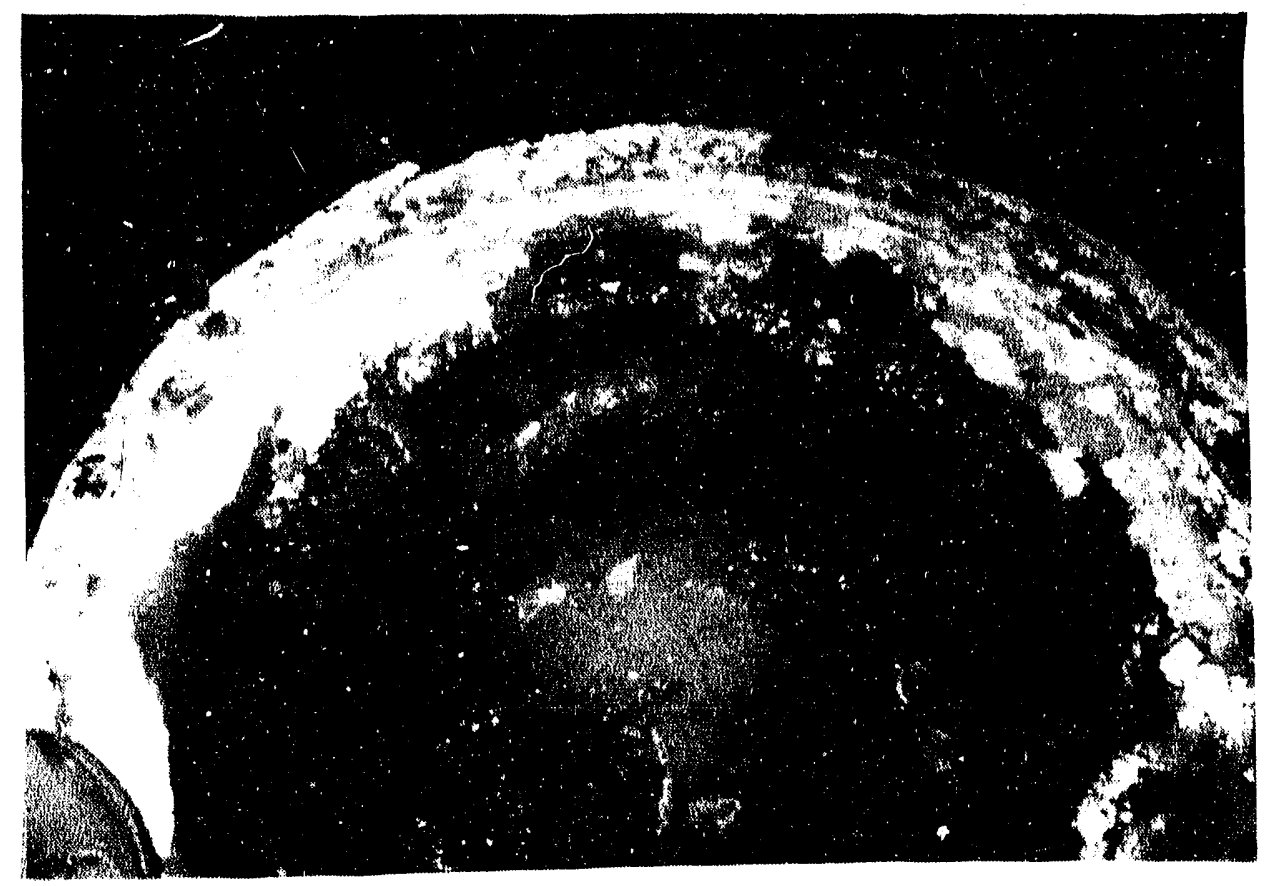

Figure 7. Photograph of tilt furnace with top half removed aiter test showing erosion of refractory in lower part of furnace. 


\subsection{Chemical Analysis}

Samples $(500-600 \mathrm{~g})$ were randomly selected from each batch, ground to -10$)$ mesh $(<149 \mu \mathrm{m})$, and submitted to an independent EPA-certified analytical laboratory ${ }^{23}$ for total metals and EPA toxicity characteristic leachate procedure (TCLP) analysis.

The analysis reported in Table 5 was performed using standard nitric acid leach procedure to dissolve the analytes followed by inductively coupled plasma (ICP) analysis. This procedure only partially dissolves alumina, silica, and iron alumina-silicates resulting in lower analytical values for aluminum, silicon, and iron than actually present. X-ray florescence (XRF) spectroscopy was used to determine alumina, silica, and iron oxide contents as reported in Table 1.

Results for total metals analysis in several samples is shown in Table 5. Sample \# A-1a to A-5 are from vitrified soil only. Sample \#B-1 to B-5 are from vitrified soil which had sodium carbonate llux added. Samples C-1 and C-2 are raw INEL soil.

All of the metals contained in the spike $(\mathrm{Ag}, \mathrm{Cr}, \mathrm{Hg}, \mathrm{Pb}$, and $\mathrm{Zn})$ analyze to be at or near background levels i.e., levels found in raw soil. A large share of the weight loss observed in these tests may be due to volatilization of the metal nitrate additives. The soil was fed as a fine powder and dropped by the serew feeder directly through the plasma plume on its way to the melt, thus contributing to the volatilization.

Table 6 gives the results of the TCLP tests. The last line in Table 6 shows values for EPA limits on metals concentration in the acid leachate. All of the samples submitted for analysis had metal leach concentration well below the required EPA limits. This is not an unexpected result in light of the results from total metals analysis in the slag shown in Table 5. Concentration of all the metals additives 10 the soil were at or near background levels in the slag.

The capacity of INEL soil to chemically bind metal ions is demonstrated in the TCLP test results for the raw soil (Samples C-1 and C-2). From Table 5 it can be seen that raw soil contained levels of chromium, lead, and mercury several times the EPA limits for these metals. Results from TCLP analysis in Table 6 show the amounts of these metals in the leachate well below the required EPA limits.

\subsection{Microstructure and Phase Composition of the Vitrified Soil}

It is important to identify the phases and composition of different phases in the slag in order to determine the physical and chemical (leaching) stability of the potential final waste form. 
Table 5. Concentrations of metals in vitrified soil.

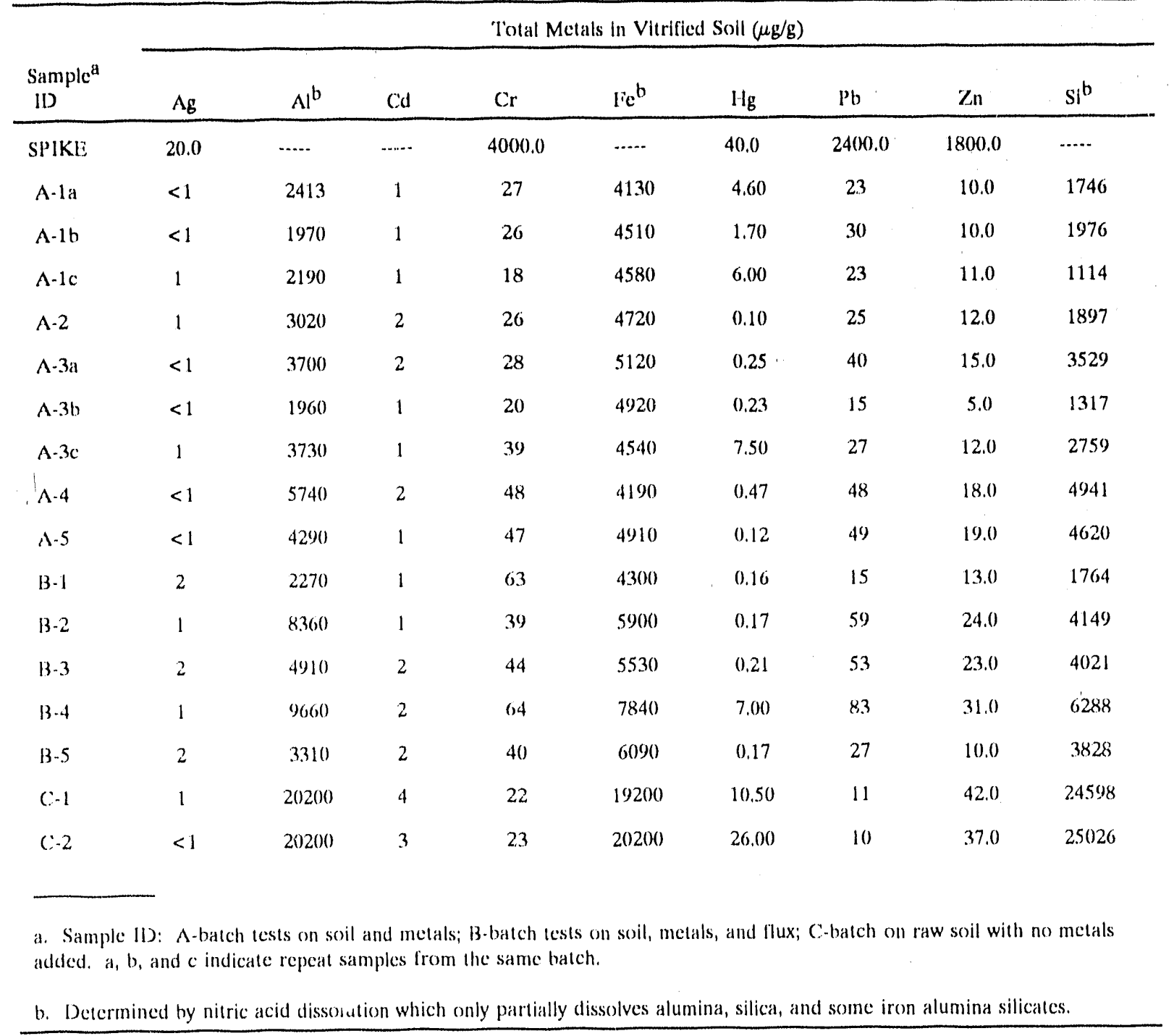


Table 6. Results of toxicity characteristic leachate procedure (TCLP) tests.

\begin{tabular}{|c|c|c|c|c|c|c|c|c|}
\hline \multirow{2}{*}{$\begin{array}{l}\text { Sample } \\
\text { II) }\end{array}$} & \multicolumn{8}{|c|}{ Total Metals Leached from Vitrifled Soll - IBPA-TCLP'Test $(\mu \mathrm{g} / \mathrm{g})$} \\
\hline & $\mathrm{Ag}$ & $\mathrm{Cr}$ & $\mathrm{Hg}$ & Ph & 211 & Ba & $\mathrm{Sc}$ & As \\
\hline$\Lambda-1 a$ & $<0,01$ & 1.06 & $<0.0(0) 4$ & 0.12 & 0.2 & 0.5 & $<0,01$ & $<0.01$ \\
\hline$A-1 b$ & $<0.01$ & 0.78 & $<0.00(0) 4$ & 0.37 & 0.2 & 0.6 & $<0.01$ & 0.01 \\
\hline$\Lambda-1 c$ & $<0.01$ & 0.68 & $<0.0004$ & 0.29 & 0.1 & 2.1 & $<0.01$ & 0.01 \\
\hline$A-2$ & $<0.01$ & 0.63 & $<0.0004$ & 0.23 & 0.1 & 0.5 & $<0.01$ & $<0.01$ \\
\hline$A-3 a$ & $<0.01$ & 0.59 & $<0.0004$ & 0.26 & 0.1 & 0.5 & $<0.01$ & 0.01 \\
\hline$A \cdot 3 b$ & $<0.01$ & 0.65 & $<0.0004$ & 0.16 & 0.1 & 0.3 & $<0.01$ & 0.01 \\
\hline$A \cdot 3 c$ & $<0.01$ & 0.47 & $<0.0004$ & 0.68 & 0.2 & 0.2 & $<0.01$ & 0.01 \\
\hline$A \cdot 4$ & $<0,01$ & 0.43 & $<0.0(0)(4$ & 0.28 & 0.1 & 0.2 & $<0.01$ & 0.01 \\
\hline A. .5 & $<0.01$ & 0.48 & $<0.0(0)(04$ & 0.30 & 0.1 & 0.2 & $<0.01$ & 0.01 \\
\hline$B-1$ & $<0.01$ & 0.47 & $<0.0004$ & 0.41 & 0.2 & 0.3 & $<0,01$ & 0.02 \\
\hline B. 2 & $<0.01$ & 0.53 & $<0.0004$ & 0.46 & 0.2 & 0.4 & $<0.01$ & 0.03 \\
\hline B.3 & $<0.01$ & 0.54 & $<0.0004$ & 0.44 & 0.2 & 0.3 & $<0.01$ & 0.01 \\
\hline 13.4 & $<0.01$ & 0.59 & $<0.00104$ & 0.63 & 0.3 & 0.8 & $<0.01$ & 0.01 \\
\hline B-5 & $<0.01$ & 0.53 & $<0.0004$ & 0.36 & 0.2 & 0.3 & $<0.01$ & $<0.01$ \\
\hline$C-1$ & $<0.01$ & 0.02 & $<0.00(104$ & 0.010 & $<0.1$ & 3.9 & $<0.01$ & $<0.01$ \\
\hline$\therefore-2$ & $<0.01$ & 0.02 & $<0.00004$ & 0.009 & $<0.1$ & 3.9 & $<0.01$ & 0.01 \\
\hline $\begin{array}{l}\text { liPA } \\
\text { Limits }\end{array}$ & 5.00 & 5.00 & 0.20 & 5.00 & $\ldots \ldots$. & 100.00 & 1.00 & 5.00 \\
\hline
\end{tabular}


After melting, the slag was poured into a bed of sand and cooled over a period of 1-2 hours. Figure 8 is a photograph of slag sample PEC B-4 showing the variety of greenish brown and black streaks that occur in different regions of the sample. Other parts of the slag are a relatively uniform, black, glassy obsidian.

Scanning electron microscopy (SEM) and emission dispersive spectroscopy (EDS) were used to identify the microstructure and chemical phase composition of vitrified samples. Typical photomicrographs are shown in Figures 9-16. As a result of the relatively rapid cooling, the microstructure is quite fine with small crystals and dendrites distributed throughout the predominantly glass matrix. The composition of the slag is determined at the EDS spots identified in Figures 9-16, using a $1-\mu \mathrm{m}$ square probe area. Differences in the microstructure may be due to variations in the feed time, hold time, and pour temperature (see Table 4). The resulting composition of the various phases in wt \% is given in Table 7 for the A and B series. Note that the original material was INEL soil with the addition of nitrates which appear to have been vaporized early in the processing. In addition, Series $\mathrm{B}$ included sodium carbonate to provide $5 \% \mathrm{Na}_{2} \mathrm{O}$ in the melt.

The crystals appear in blocky, small, and needle forms, as well as a cross-type form that looks like it grew out of a dendrite. The slag is formed by processes differing from those in nature, pressure, temperature, and time; therefore, the various crystal, dendrite, and glass compositions do not necessarily fit the definitions of naturally-occurring, well-documented minerals. The larger, blocky, white crystals (Groups AA and BA in Table 7) are predominantly a binary mixture and/or solution of the oxides, $\mathrm{Al}_{2} \mathrm{O}_{3}$ and $\mathrm{Cr}_{2} \mathrm{O}_{3}$. Groups $\mathrm{AB}$ and $\mathrm{BB}$ crystals have a spinel composition $\left(\mathrm{R}^{+2} \mathrm{R}^{+3}{ }_{2} \mathrm{O}_{4}\right)$ with varied elements. The $\mathrm{BC}$ crystal group contains too much silica for a spinel and may be an orthosilicate. Pyroxene and feldspar mineral groups are not probable because of the whiteness (high reflectivity) of the crystals. Similar comments apply to the needle shaped crystals, Groups $\mathrm{AC}$ and $\mathrm{BD}$. The question of the probe picking up the silica from the background aluminosilicate glass is presumably answered by the absence of any $\mathrm{Mg}$ in PECA4-3. The dendrites (Groups AD and BE) are another paradox, because of the whiteness and the high silica eontent. The pyroxenes and feldspars have been found to be varying shades of grey in prior IEB research ${ }^{24}$ and recent SEM/EDS analysis of slag from the plasma are furnace experiment (PAFE) by INEL/MSE in Butte, Montana. $^{25}$ For the dendrites, some silica may be measured from the glass between the dendritic formations. In the PAFE case, the slag was cooled in 1-2 days (not hours) which led to a higher fraction and larger size crystal formation, with white dendrites that did not contain significant amounts of silica. The glass away from (Groups AE and BF) and between (Groups AF \& BG) crystals have essentially the same compositions, with the B-series containing more sodium. The glass phase is an aluminosilicate glass with varying amounts of alkali and alkali earth elements. 


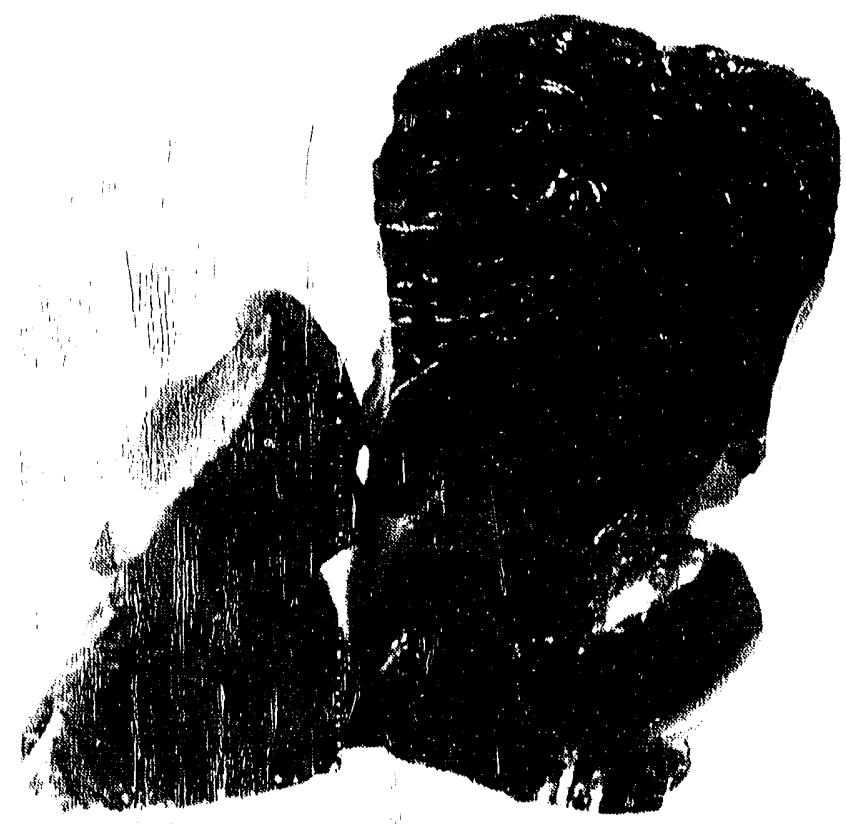

Figure 8. SEM photograph of slag sample PEC B-4 showing the variety of colored streaks that occur in different regions of the sample. 


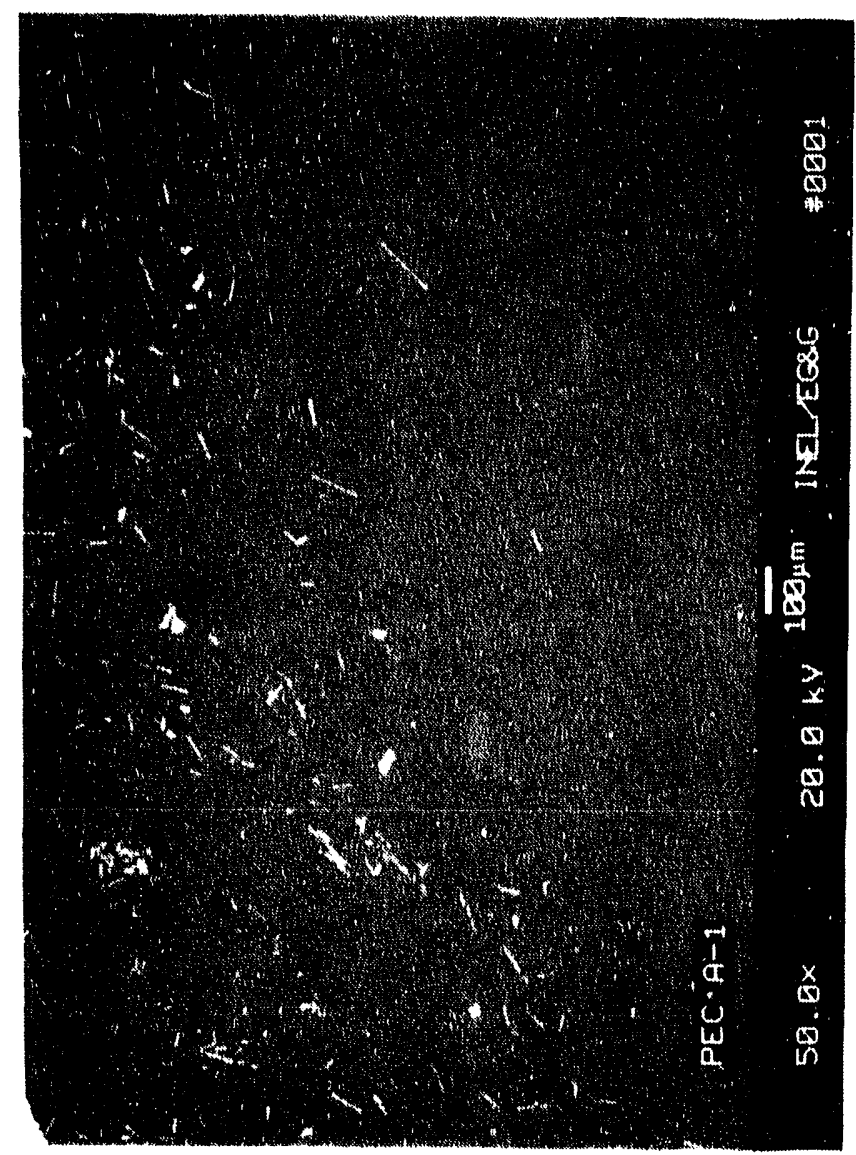

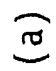
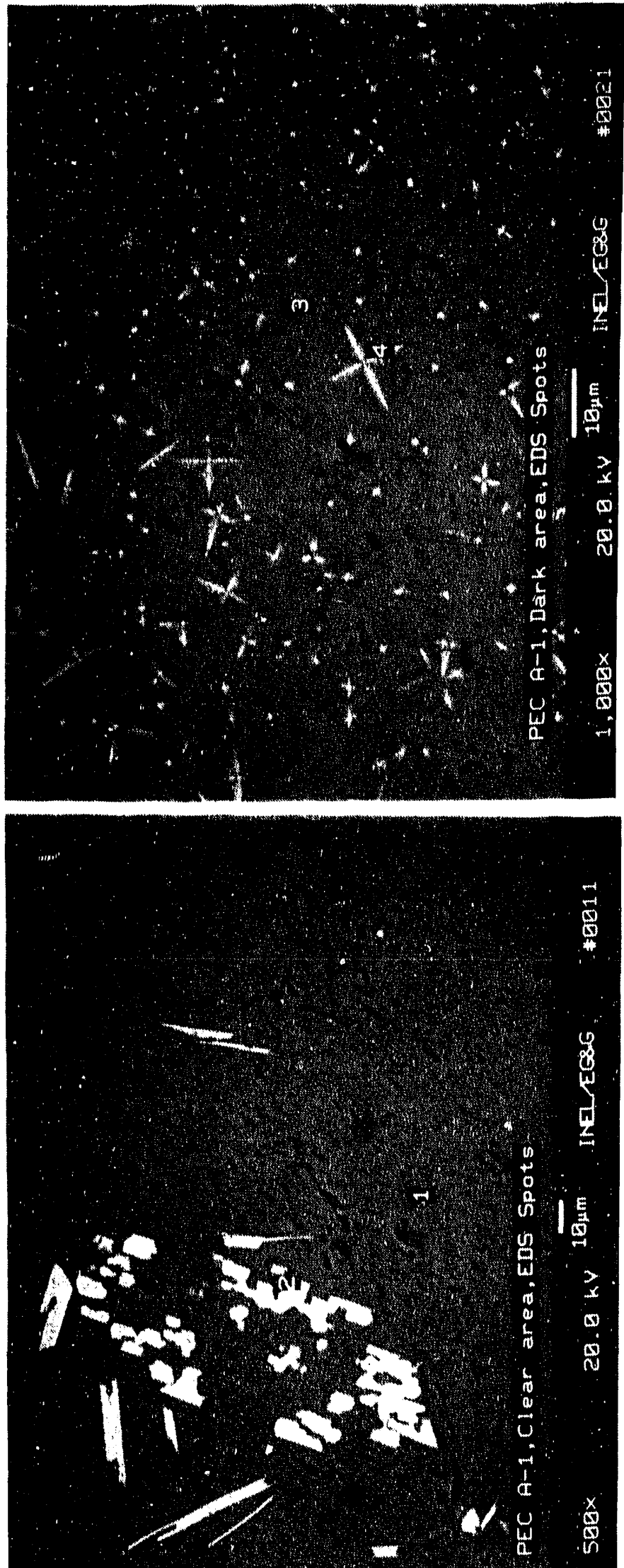

管

至

可

늘

界

s

용

$. \Xi \pm$

훙 욤

च

象的

吉希

4 है.

음ㅁㅁ

至

政㑹

\%

की

들 뭄

ए 营

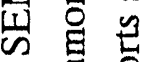

๙

का प्त क

。

总員占 
(a)

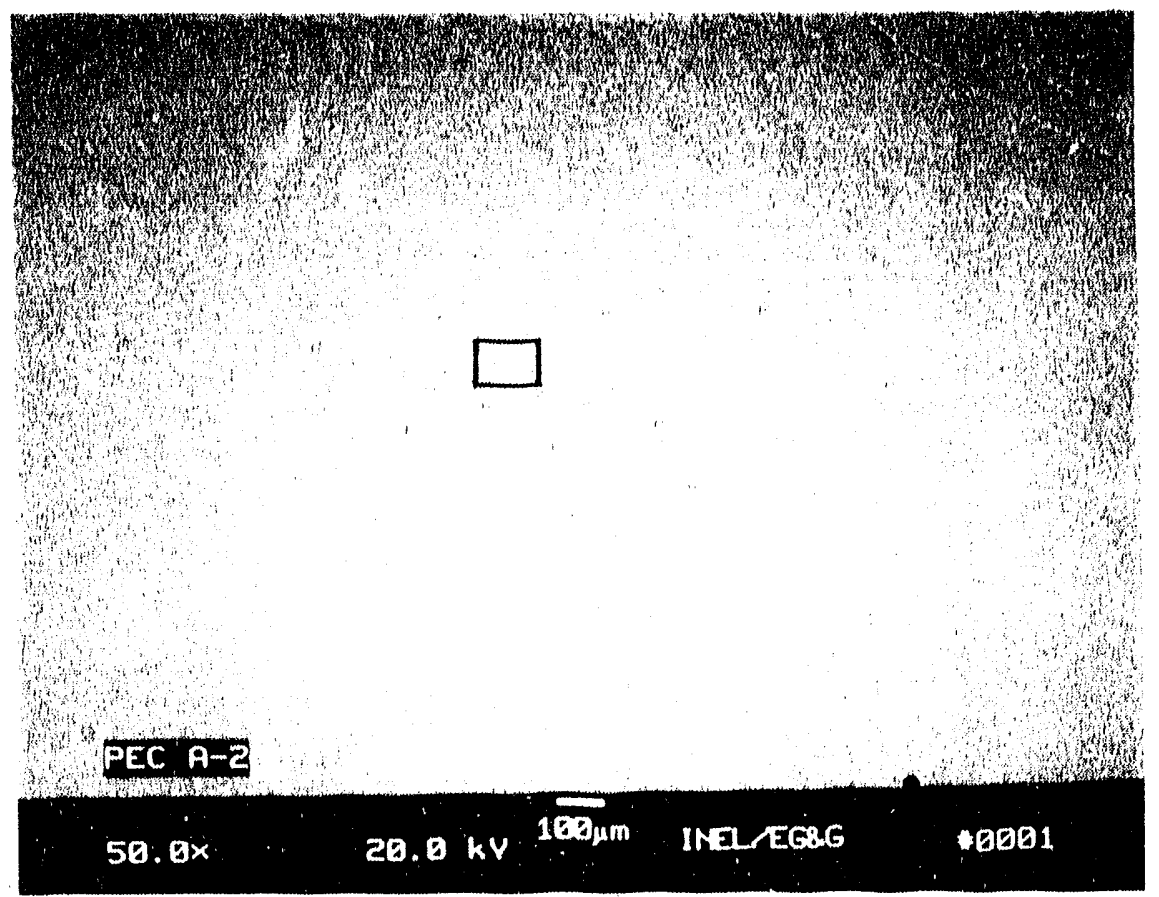

(b)

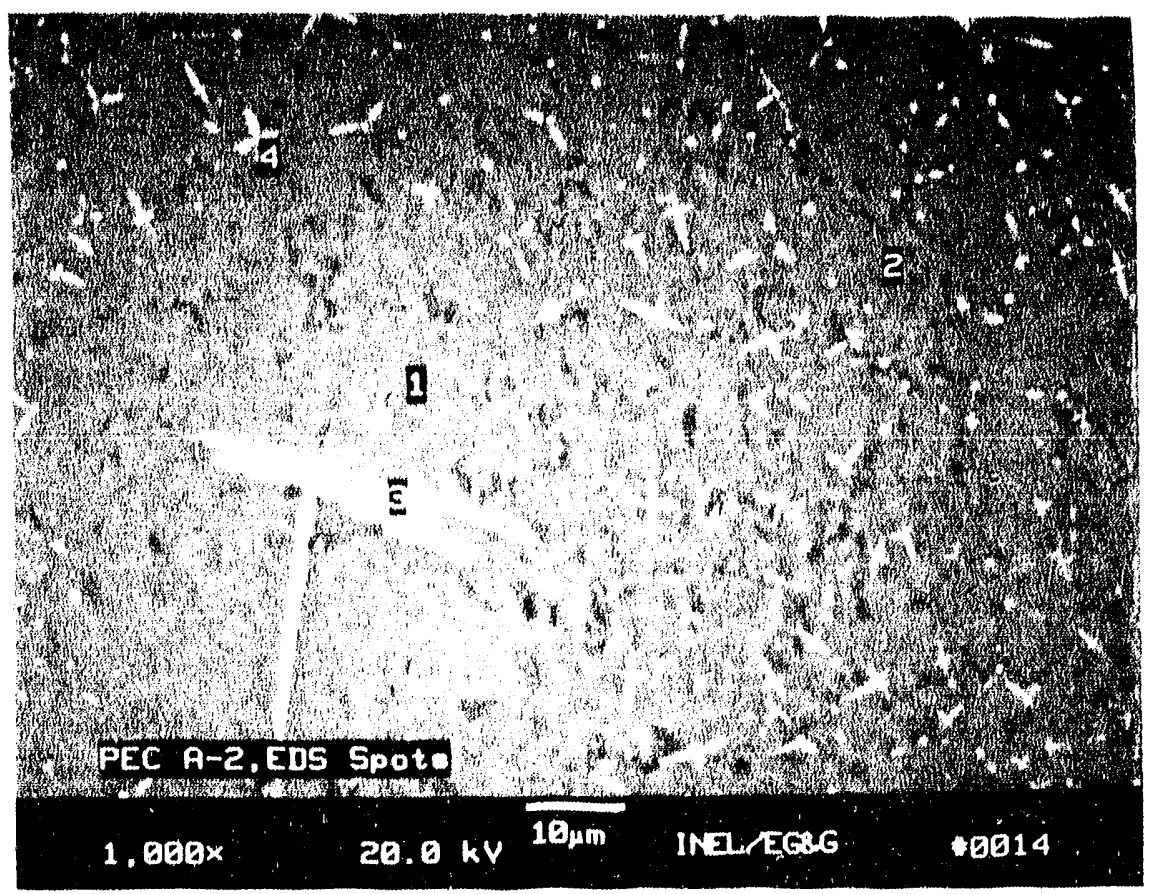

Figure 10. SEM photographs of vitrified soi! in slag sample PEC A-2 showing microstructure at (i) $50 \mathrm{X}$ showing the predominantly amorpho 1 s glass phase and small size of the crystals and (b) 100() $\mathrm{X}$ showing the blocky dendritic phases. 
(a)

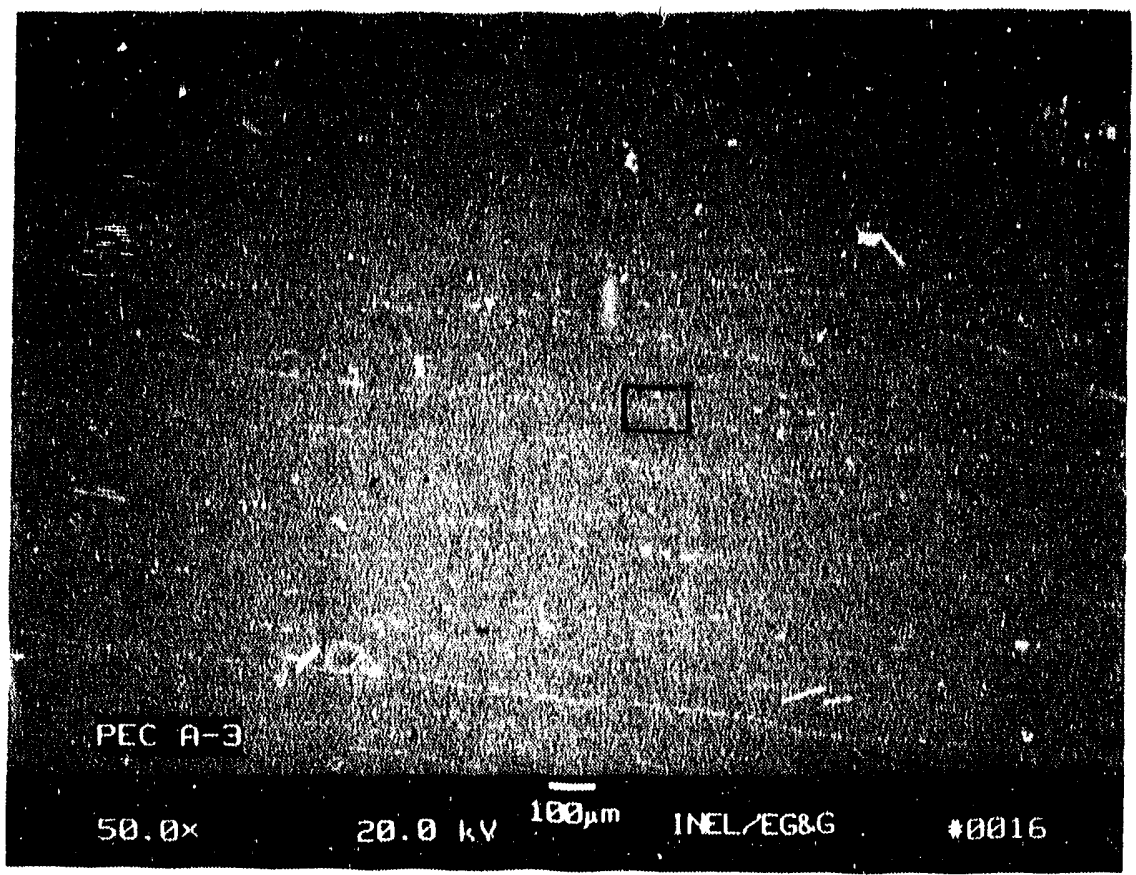

(c)

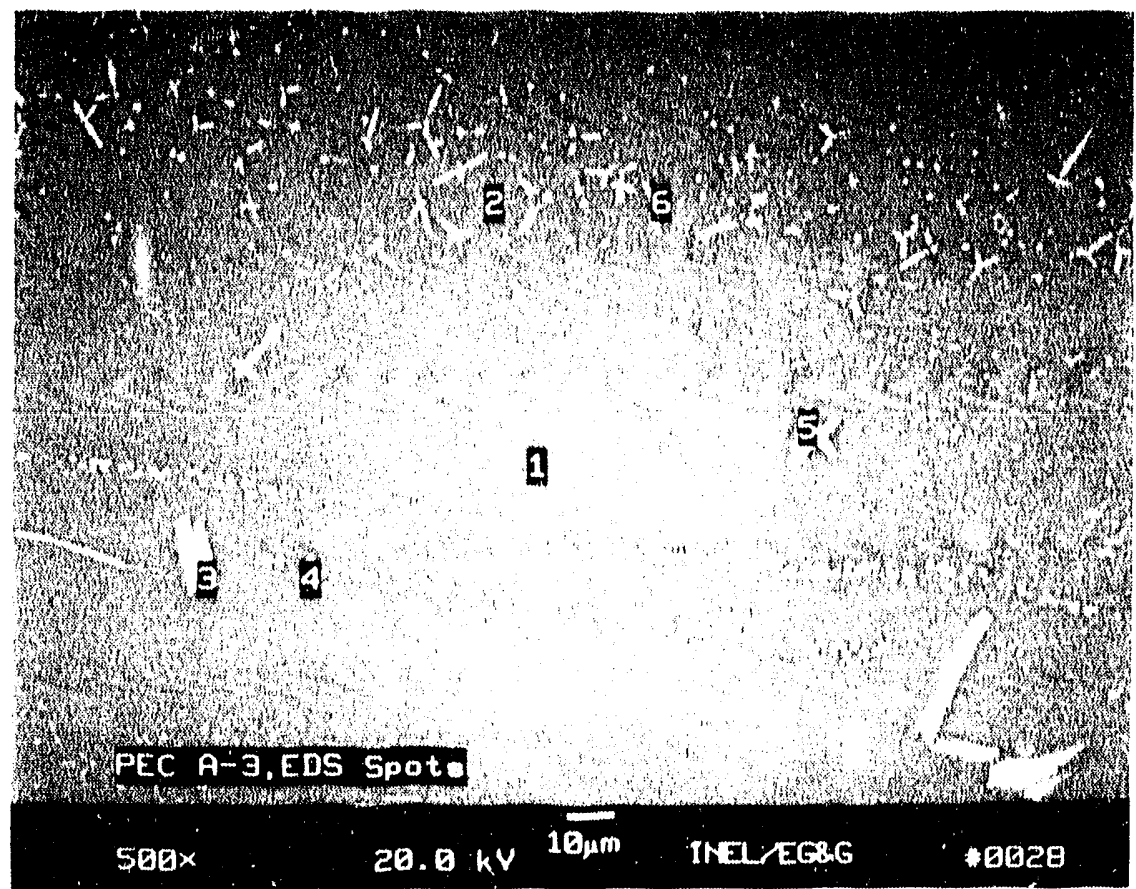

Figure 11. SEM photographs of vitrified soil in slag sample PEC A-3 showing microstructure at (a) $50 \mathrm{X}$ showing a streaky set of small crystals in the predominantiy glass phase and (b) $500 \mathrm{X}$ showing the various crystalline structure. 

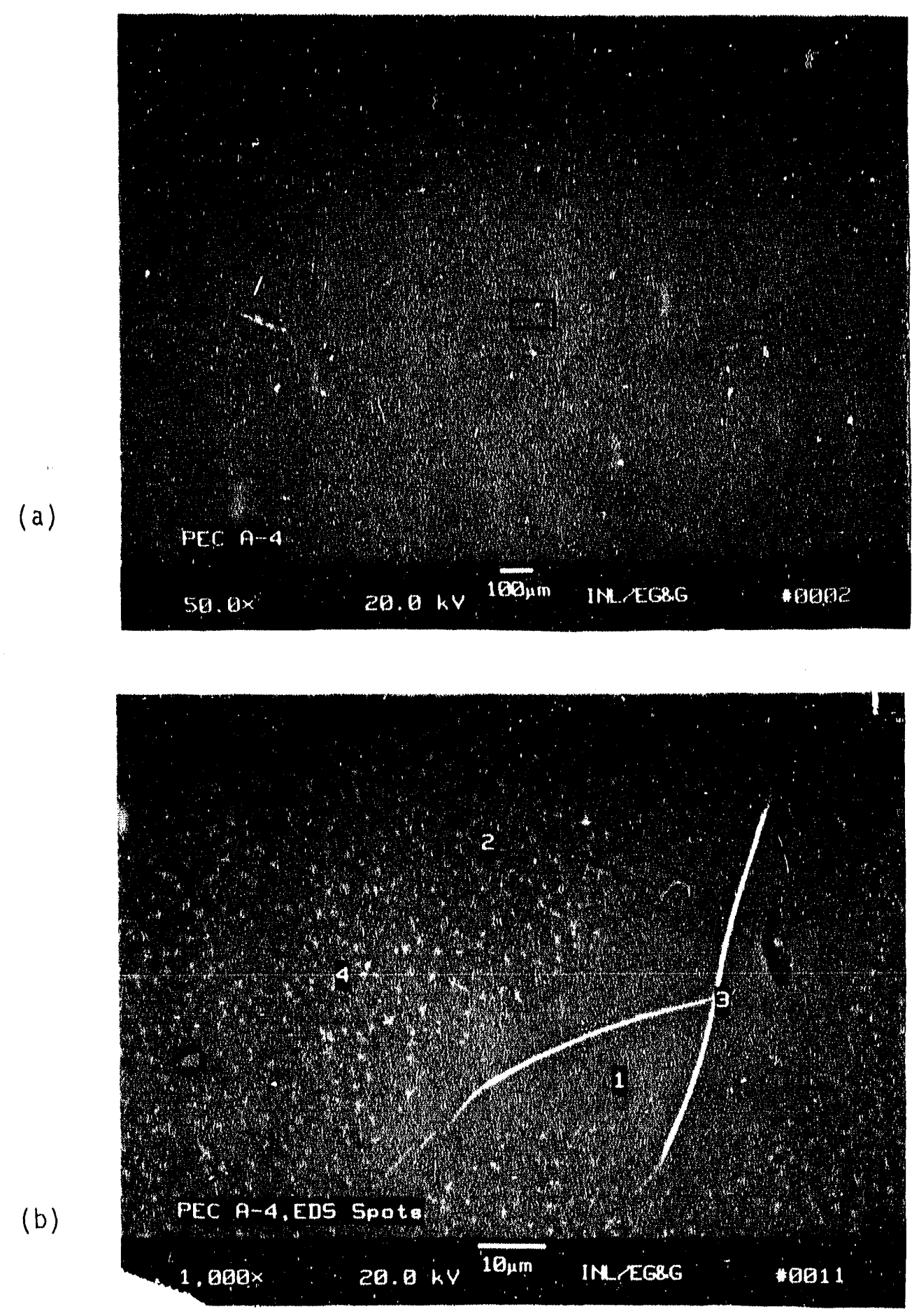

Figure 12. SEM photographs of vitrilied soril in slang sample PEC A-4 at (a) 50X showing the extremely small crystals in the predominantly amorphous glass phase and (b) 1000X showing the needle shaped and dendritie crystals: 

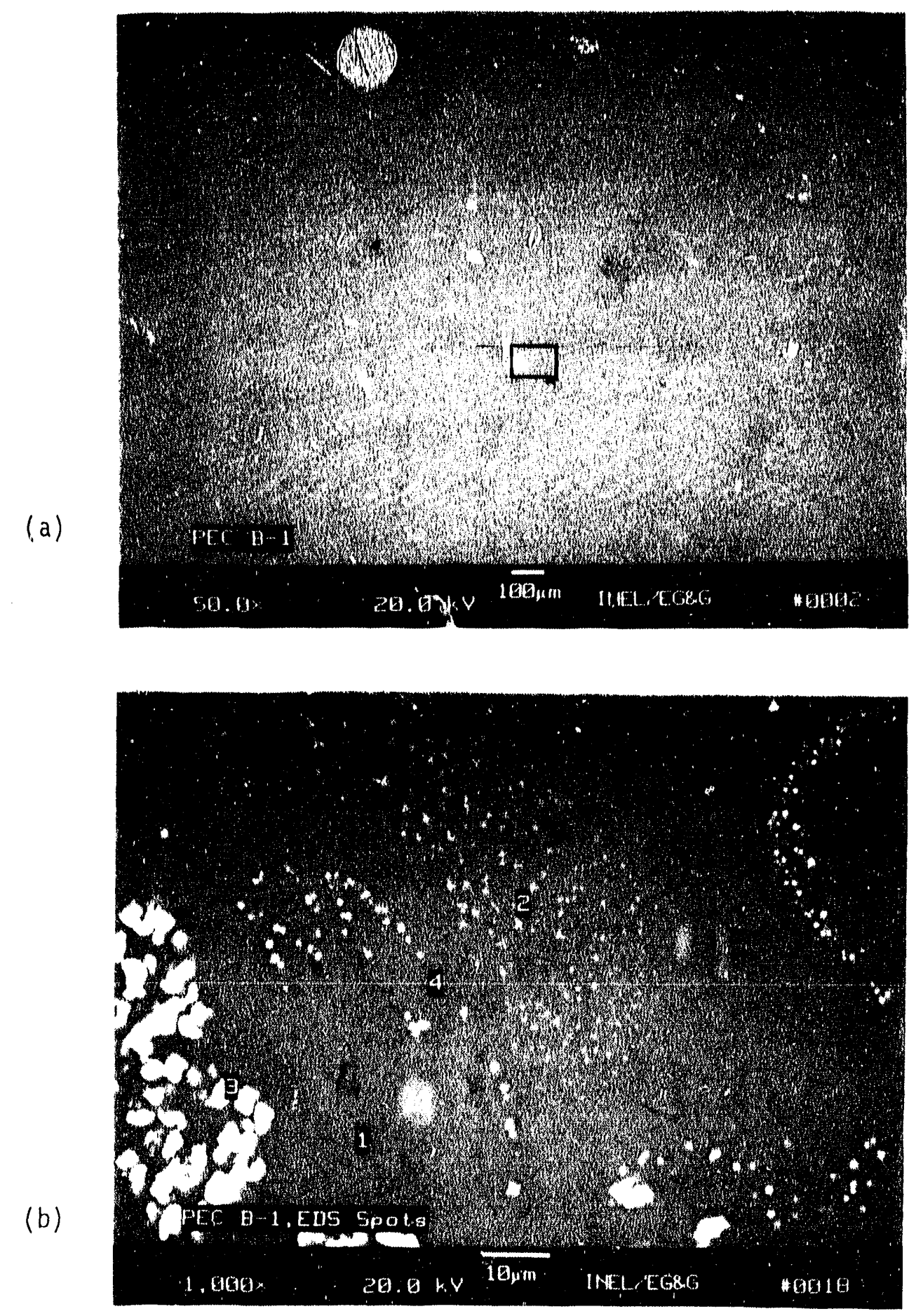

Figure 13. SEM photographs of vitrificd soil microstructure in sample PEC B-1 at (a) $50 \mathrm{X}$ showing crystal groups in the predominantly amorphous glass phase and (b) 10(0)X showing the blocky, small, dendritic shaped crystals. 
(a)

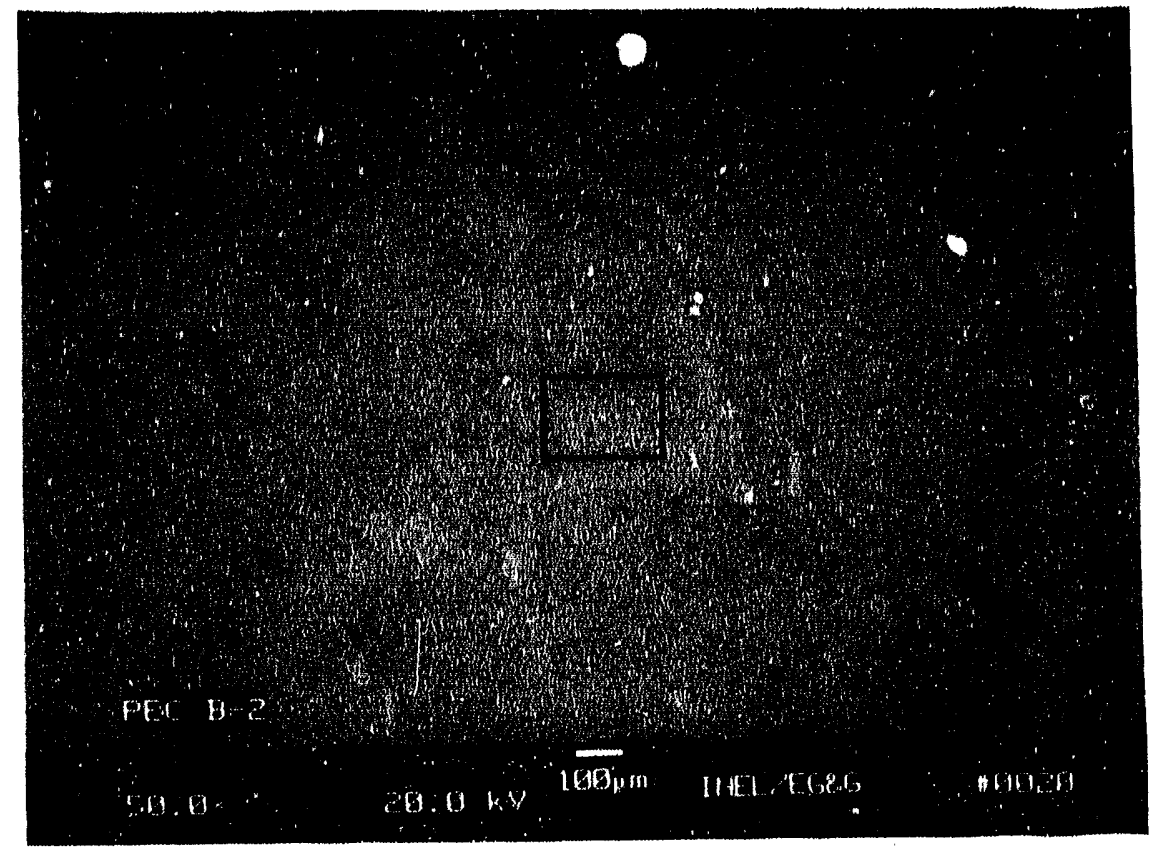

(b)

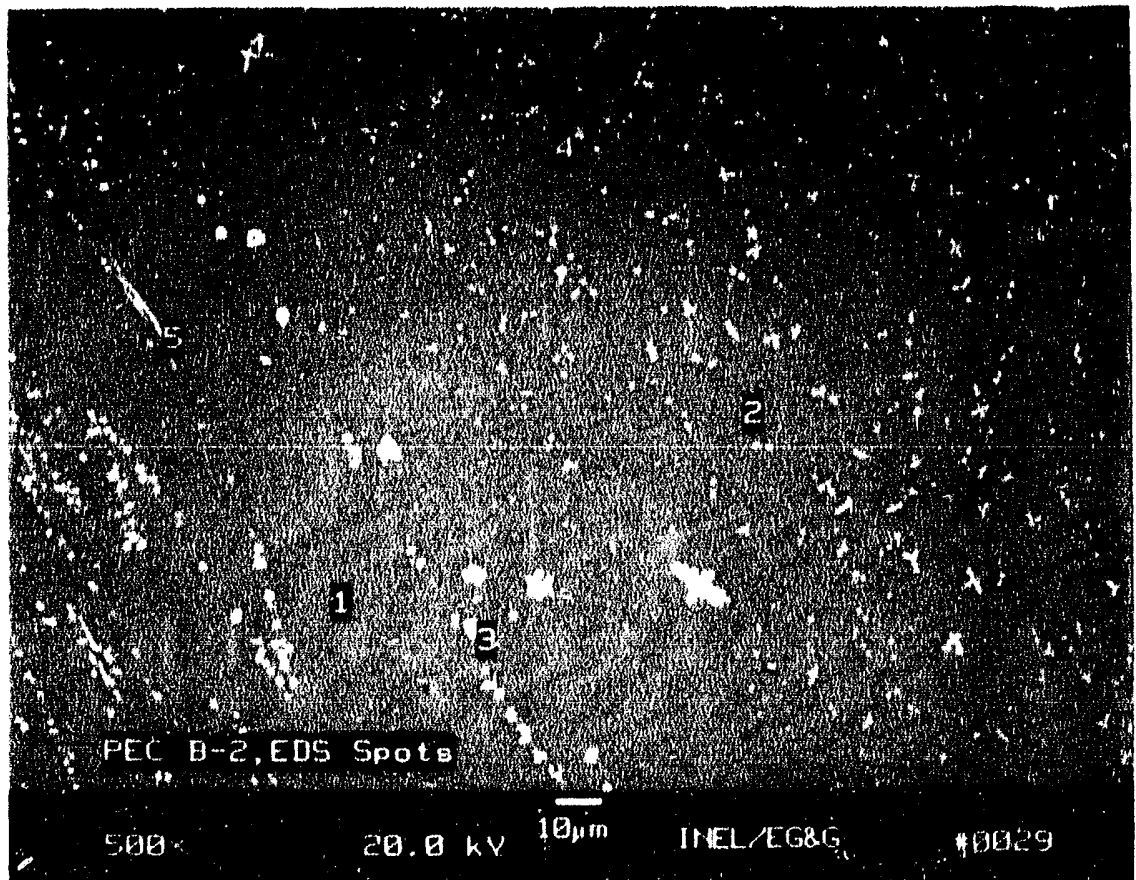

Figure 14. SEM photographs of vitrified soil microstructure in sample PEC B-2 at (a) 50X showing the predominantly amorphous phase from the rapid cooling and (b) $5(K) \mathrm{X}$ showing needle and other crystalline structure. 
(a)
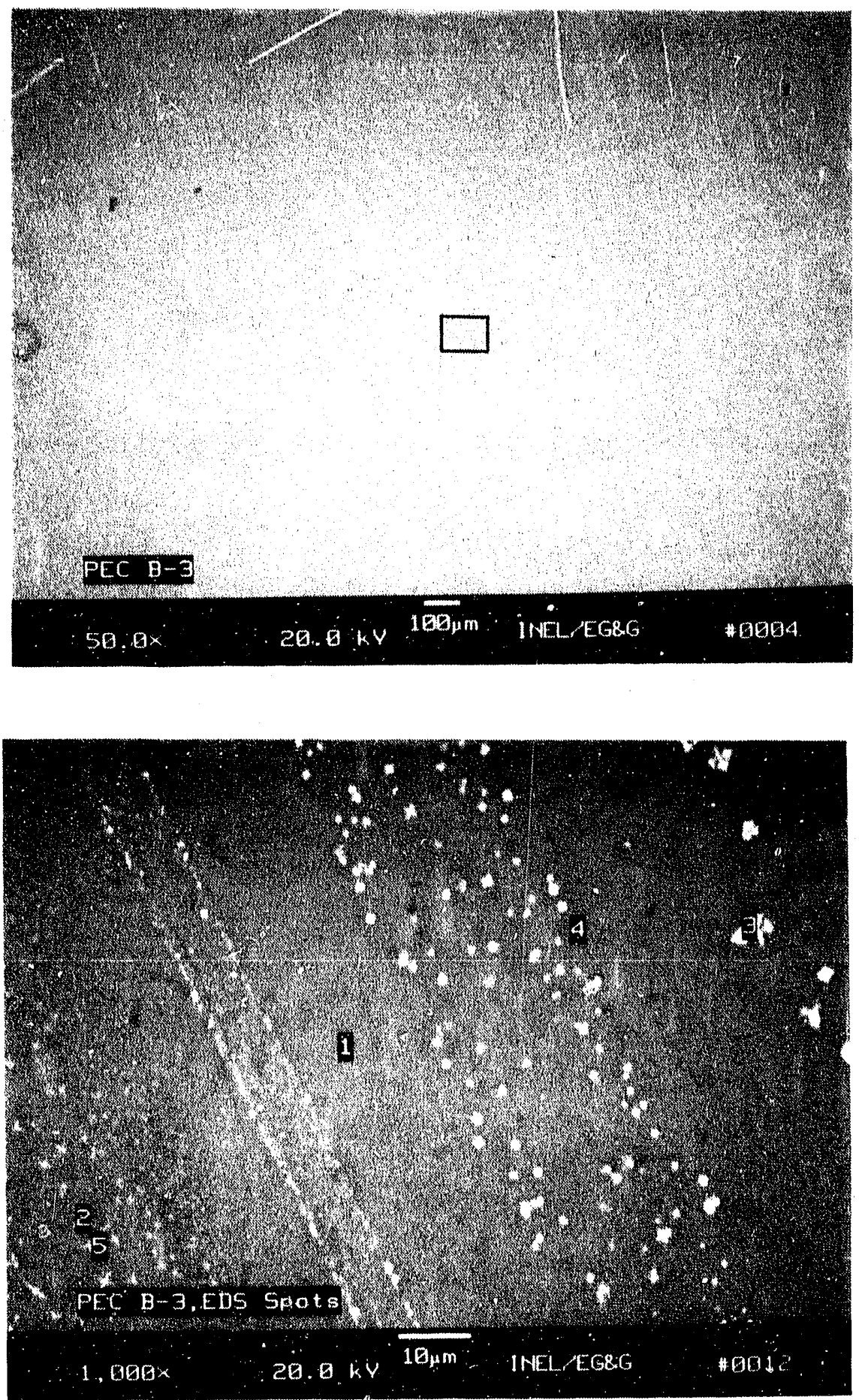

Figure 15. SEM photographs of vitrified soil microstructure in sample PEC B-3 (a) 50X showing some crystal groups and the predominantly amorphous glass phase from the rapid cooling and (b) $1000 \mathrm{X}$ showing the streaky formation of crystals. 

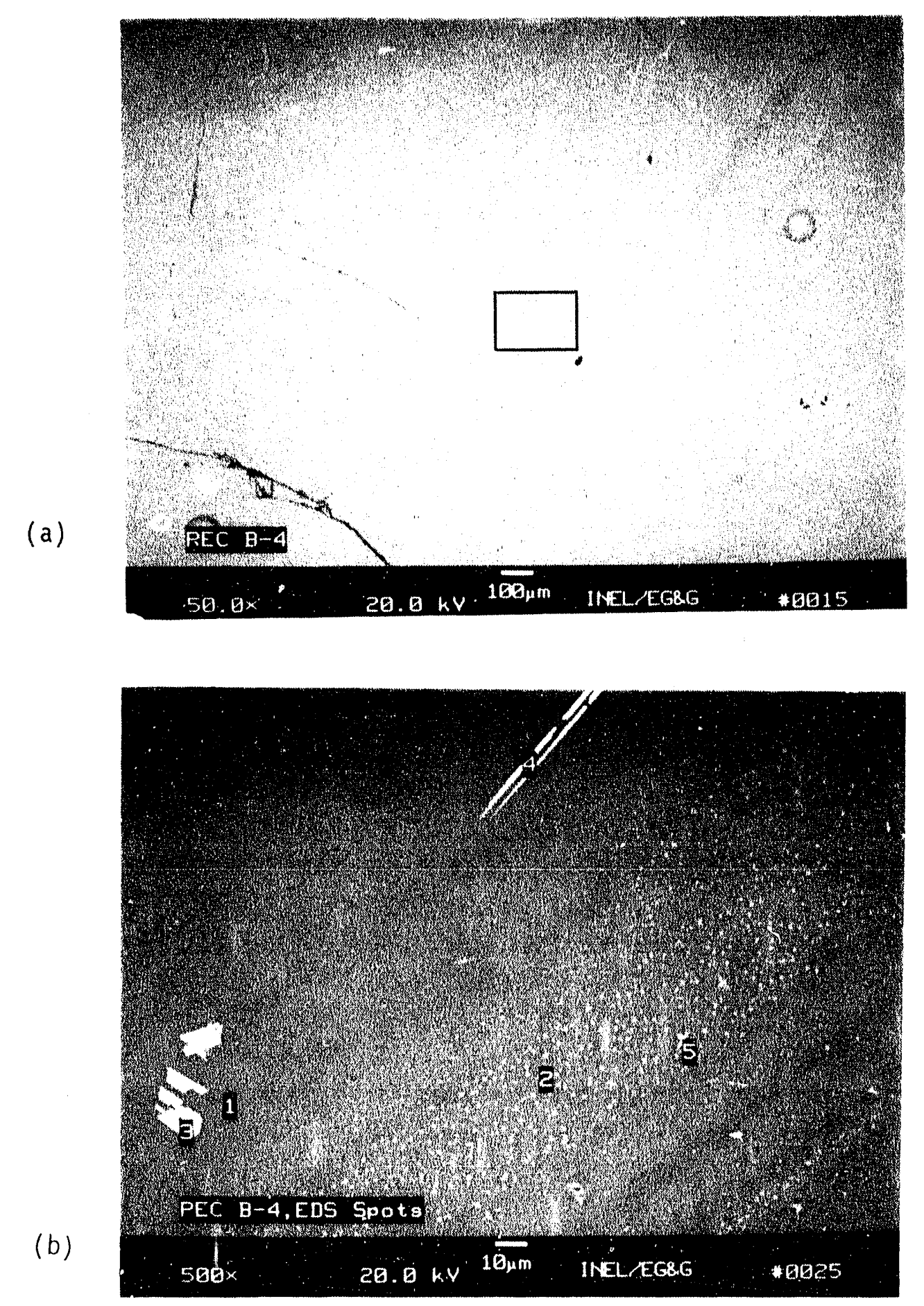

Figure 16. SEM photographs of vitrified soil in sample PEC B-4 at (a) 50X showing a different type of microstructure and (b) 500X showing a mixture of needles, blocky, small, and dendritic crystals. 
Table 7. PEC series slag composition (wt\%) via standardless EDS analysis."

\begin{tabular}{|c|c|c|c|c|c|c|c|c|c|c|c|c|c|}
\hline Group & Sample & 'Iype & $\mathrm{Na} 2 \mathrm{O}$ & $\mathrm{MgO}$ & $\mathrm{A} / 203$ & $\mathrm{SiO} 2$ & $\mathrm{~K} 2 \mathrm{O}$ & $\mathrm{CaO}$ & 'IiO2 & $\mathrm{MnO}$ & $\mathrm{Ie} 304$ & $\mathrm{Cr} 2 \mathrm{O} 3$ & $\mathrm{ZnO}$ \\
\hline \multicolumn{14}{|c|}{ ASIIRILS } \\
\hline \multirow[t]{3}{*}{$A A$} & PECA3-3 & BL,OCKY X & $\ldots$ & $\cdots$ & 58.36 & 1.77 & $\cdots$ & $\ldots .$. & 0.18 & $\cdots$ & 1.91 & 37.77 & $\ldots$ \\
\hline & PECA1-2 & BLOCKY X & $\ldots$ & $\ldots$ & 38.71 & 0.95 & $\cdots$ & .... & 0.25 & $\cdots$ & 2.50 & 57.59 & $\ldots$ \\
\hline & PECA2-3 & BLOCKY X & $\cdots$ & $\cdots$ & 16.67 & 0.88 & $\cdots$ & 0.39 & 0.61 & $\cdots$ & 6.72 & 74.74 & $\cdots$ \\
\hline \multirow[t]{2}{*}{$A B$} & PECA3.4 & SMALL X & $\cdots$ & 13.82 & 37.70 & 6.51 & 0.12 & 0.39 & 0.15 & $\cdots$ & 15.50 & 23.00 & 2.81 \\
\hline & PECA3-5 & SMALL $X$ & $\cdots$ & 15.73 & 30.09 & 2.31 & $\cdots$ & $\cdots$ & 0.11 & $\cdots$ & 16.35 & 32.08 & 3.33 \\
\hline$A C$ & PECA4-3 & NEEDILI: $X$ & $\cdots$ & $\cdots$ & 25.61 & 45.11 & 1.10 & 2.61 & 0.37 & $\cdots$ & 2.86 & 22.34 & $\cdots$ \\
\hline \multirow[t]{4}{*}{$A D$} & PECA1-4 & DENDRIIIE & 0.00 & 5.72 & 16.75 & 53.02 & 1.66 & 2.48 & 0.43 & $\cdots$ & 8.83 & 9.73 & 1.39 \\
\hline & PECA2-4 & LARGE & 0.00 & 4.99 & 19.35 & 56.23 & 1.64 & 2.73 & 0.29 & $\cdots$ & 8.32 & 5.52 & 0.94 \\
\hline & PI:CA3-6 & SMALL & $\ldots$ & 5.89 & 26.52 & 48.34 & 1.47 & 1.88 & 0.20 & $\cdots$ & 7.76 & 6.94 & 1.00 \\
\hline & PECA4-4 & SMAIL. & 0.00 & 3.29 & 23.69 & 57.49 & 1.69 & 3.26 & 0.35 & $\cdots$ & 4.82 & 4.92 & 0.50 \\
\hline \multirow[t]{4}{*}{$\mathrm{Al}:$} & PlOCAl-1 & GLASS & $\cdots$ & 2.99 & 12.56 & 61.06 & 1.69 & 3.66 & $\cdots$ & 0.57 & 17.47 & $\cdots$ & $\cdots$ \\
\hline & PECA2-1 & GIASS & 1.30 & 1.85 & 17.50 & 68.97 & 2.21 & 5.01 & 0.46 & $\cdots$ & 2.53 & 0.18 & $\ldots$. \\
\hline & PI:CA3-1 & GLASS & 1.37 & 1.67 & 22.87 & 64.42 & 1.90 & 5.10 & 0.44 & $\cdots$ & 2.23 & $\cdots$ & $\cdots$ \\
\hline & PICA4-1 & GLASS & 1.49 & 1.87 & 23.5 .5 & 63.20 & 1.89 & 4.87 & 0.55 & $\cdots$ & 2.44 & 0.16 & $\cdots$ \\
\hline \multirow[t]{4}{*}{$\mathrm{Al}$} & PI:CA1-3 & GIASS & 1.55 & 2.28 & 16.88 & 68.63 & 2.02 & 5.46 & 0.49 & $\cdots$ & 2.57 & 0.12 & $\ldots$. \\
\hline & P1:CA2-2 & BEIWEEN & 1.62 & 2.05 & 17.61 & 68.46 & 2.15 & 5.18 & 0.51 & $\cdots$ & 2.42 & $\cdots$ & $\cdots$ \\
\hline & PECA $3-2$ & DEND- & 1.35 & 1.42 & 23.15 & 64.04 & 1.85 & 5.38 & 0.51 & $\cdots$ & 2.23 & 0.06 & $\cdots$ \\
\hline & PECA4-2 & RI'IEES & 1.64 & 1.52 & 23.24 & 63.80 & 1.82 & 5.06 & 0.56 & $\cdots$ & 2.14 & 0.22 & $\cdots$ \\
\hline \multicolumn{14}{|c|}{ B-SliRIISS } \\
\hline \multirow[t]{3}{*}{$B A$} & PECB4-3 & BLOCKY X & $\cdots$ & $\cdots$. & 31.54 & 0.61 & $\cdots$ & 0.29 & 0.46 & 0.32 & 6.08 & 60.70 & $\cdots$ \\
\hline & PICB 2-5 & NEEDLE $X$ & 1.88 & $\cdots$ & 35.81 & 10.65 & 0.19 & 0.55 & 0.38 & 0.32 & 3.20 & 47.02 & $\cdots$ \\
\hline & PECB $1-3$ & BLOCKY X & 0.81 & 0.00 & 21.72 & 13.17 & 0.32 & 0.84 & 0.48 & 0.35 & 5.92 & 56.40 & $\cdots$ \\
\hline \multirow[t]{2}{*}{$B B$} & PLCB2-3 & BLOCKY X & 0.00 & 14.78 & 23.61 & 7.23 & 0.19 & 0.48 & 0.22 & 0.44 & 15.92 & 33.59 & 3.55 \\
\hline & PEC:B3-3 & $\operatorname{CROSS} x$ & 1.45 & 13.85 & 15.83 & 17.28 & 0.43 & 0.65 & 0.24 & 0.37 & 17.19 & 29.40 & 3.31 \\
\hline \multirow[t]{2}{*}{$B C$} & PEC.B 1-4 & SMAILL X & 3.54 & 7.34 & 15.98 & 40.82 & 0.98 & 1.89 & 0.25 & 0.22 & 11.62 & 15.21 & 2.14 \\
\hline & PF:CB3-4 & SMALL $X$ & 3.72 & 7.66 & 17.23 & 39.12 & 0.93 & 1.67 & 0.32 & 0.17 & 12.16 & 15.14 & 1.88 \\
\hline BD & PEC:B4-4 & NEEIDILE $X$ & 4.56 & 0.61 & 17.87 & 46.26 & 1.37 & 3.49 & 0.55 & $\cdots$ & 4.07 & 21.22 & $\cdots$ \\
\hline \multirow[t]{4}{*}{$B E$} & PI:CB]-5 & DENDRIIIE & 4.62 & 4.37 & 15.28 & 52.20 & 1.57 & 2.59 & 0.38 & 0.10 & 8.67 & 9.10 & 1.12 \\
\hline & PECB2-4 & SMAIL. & 3.07 & 7.22 & 26.42 & 41.34 & 0.98 & 1.65 & 0.28 & 0.00 & 8.59 & 9.27 & 1.19 \\
\hline & PL:C:33.5 & SMAIII. & 3.30 & 3.71 & 15.91 & 56.51 & 1.59 & 3.61 & 0.47 & 0.01 & 10.25 & 3.77 & 0.80 \\
\hline & PI:CB4.5 & SMALI & 3.10 & 5.60 & 17.68 & 48.97 & 1.28 & 2.30 & 0.26 & $\cdots$ & 9.58 & 10.01 & 1.16 \\
\hline \multirow[t]{4}{*}{$\mathrm{BF}$} & PI:CB1-1 & GLASS & 4.83 & 1.46 & 18.75 & 64.95 & 1.95 & 4.98 & 0.47 & $\cdots$ & 2.40 & 0.20 & $\ldots$ \\
\hline & PI:CB2-1 & GLASS & 5.31 & 1.19 & 23.49 & 61.45 & 1.66 & 4.32 & 0.62 & $\cdots$. & 1.88 & 0.09 & $\cdots$. \\
\hline & PECB3-1 & GLASS & 5.13 & 1.26 & 17.78 & 66.13 & 2.01 & 4.78 & 0.48 & $\cdots$ & 2.44 & $\cdots$ & $\ldots .$. \\
\hline & PECB4-1 & GLASS & 4.75 & 1.45 & 25.54 & 58.65 & 1.53 & 5.28 & 0.49 & $\cdots$ & 2.15 & 0.18 & $\cdots$ \\
\hline \multirow[t]{4}{*}{$B G$} & PECB1-2 & GLASS & 4.95 & 1.71 & 17.03 & 66.02 & 1.91 & 4.94 & 0.46 & $\cdots$ & 2.70 & 0.28 & $\ldots$ \\
\hline & PI:CB2-2 & BI:TWIEISN & 5.17 & 1.14 & 23.24 & 61.80 & 1.67 & 4.51 & 0.59 & $\cdots$. & 1.88 & $\cdots$. & $\cdots$ \\
\hline & PEC.B3-2 & DEND- & 5.19 & 1.54 & 17.07 & 65.55 & 1.82 & 5.22 & 0.50 & $\ldots$. & 2.85 & 0.27 & $\ldots$ \\
\hline & PI:CB34-2 & RITLS & 3.94 & 1.26 & 19.05 & 66.26 & 1.90 & 4.67 & 0.52 & $\cdots$ & 2.31 & 0.10 & $\cdots$ \\
\hline
\end{tabular}

a. PECA1-2 means PEC 'Test, Series A, Run 1, SFM/EDS spot \#2; X = crystals. 


\section{CONCLUSIONS}

INEL basaltic soil was easily processed into a vitreous glassy slag in a plasma furnace. Alteration of some process parameters should make it possible to lower the specific energy requirement of the soil to ca. $1.0 \mathrm{~kW} / \mathrm{kg}$. Process changes should include running the plasma torch in the transferred mode (the melt is the negative electrode), continuous feeding and tapping in the furnace operation, design of a more efficient furnace, use of a slagging agent to increase the $\mathrm{N}_{2} \mathrm{O}$ concentration without reacting with the furnace refractory, and feeding material into the melt without passing it directly through the plasma flame.

Addition of sodium carbonate flux accomplished the objective of lowering the melting point of the soil by $\approx 200^{\circ} \mathrm{C}$. Unfortunately, high sodium levels in the melt had a deleterious effect on the refractory used in this test. Changing fluxing agent to calcium carbonate would eliminate this problem. Additional testing needs to be conducted to optimize flux composition to maximize melting point reduction and minimize refractory degradation.

Partitioning of metals within the slag was poor in these tests. This can be attributed to three problems encountered in the course of preparing and conducting the tests. These difficulties were a result of trying to simulate actual waste feed material that would be produced by the cleanup of COCA sites at TRA and limitations on the design of available plasma furnaces. The first problem was the use of a loose powdery soil as a feed material. This would simulate material removed from former waste ponds, but due to its finely divided state it was easy for volatile compounds to be evaporated from the soil before they could be incorporated into the melt. The Second problem was the use of metal nitrate compounds to spike the soil. These compounds were chosen because of the desire to simulate the chemistry of actual contaminated soil. Unfortunately, all of the metal nitrate compounds used to spike the samples melt or decompose below $5000^{\circ} \mathrm{C}$ and will evaporate or decompose rapidly in the plasma region of the furnace. The third problem resulted from feeding the powdered soil from the top of the furnace directly through the hot $(10,0(0)$ to 20,0$)(0) \mathrm{K}$ ) plasma flame. This is the region of the furnace where volatilization of metals and entrainment in the off-gas is most likely and subsequent contact with the melt least likely. This was a design limitation imposed by available plasma furnaces for this type of testing. Future experiments should be designed lo achicve maximum metals loading so that the optimum metals loading can be determined via TCLP tests.

All vitrified samples met TCLP requirements demonstrating that vitrified soil has the potential of being an excellent waste form for stabilizing inorganic species. The SEM/EDS materials characterization indicated that the metals were bound in various phases in solid solutions, and not as elemental metals, which corroborates the chemical stability. Mechanical strength of the vitrified soil was similar to other glassy slags. Flow characteristics of the molten material were quite good indicating that with the right furnace design, this material could easily be cast into permanent storage containers. 
Of the waste analogs added, only $\mathrm{Cr}$ and $\mathrm{Zn}$ were found in the slag from the EDS analysis. The $\mathrm{Pb}, \mathrm{Hg}$, and $\mathrm{Ag}$ were not found. The nitrate decomposition temperatures were quite low $\left(<500{ }^{\circ} \mathrm{C}\right)$ so that they may have decomposed immediately to $\mathrm{M}_{\mathrm{x}} \mathrm{O}$ and $\mathrm{NO}_{\mathrm{x}}$. The amounts of $\mathrm{Cr}$ and $\mathrm{Zn}$ added to the soil (and found in the slag) were significantly larger than that already resident in the soil. A comparison of the composition of the soil (see Table 1) to the EDS compositions of the slag (see Table 7) indicates the following:

- $\quad \mathrm{Al}_{2} \mathrm{O}_{3}$ increases from $9.2 \%$ to $\leq 20 \%$

- $\mathrm{CaO}$ decreases from $13.9 \%$ to $\leq 5 \%$

- $\mathrm{K}_{2} \mathrm{O}$ decreases from $5.5 \%$ to $\leq 2 \%$

with the other components staying about the same. The $\mathrm{K}_{2} \mathrm{O}$ change may be due to the sensitivity and uncertainty in the measurements. The first change can be attributed to erosion/corrosion of the refractory within the plasma furnace. Near the completion of the experiments, wall thermocouple readings indicated that there had been a loss of refractory, though there was an overall reduction in mass of approximately $10 \%$ in the output slag. In the A series, the very-high temperatures $\left(>150()^{\circ} \mathrm{C}\right)$ and in the $B$ series, the additional sodium contribute to accelerated refractory corrosion. High-temperature Ruby refractory is $10 \% \mathrm{Cr}_{2} \mathrm{O}_{3}-90 \% \mathrm{Al}_{2} \mathrm{O}_{3}$. A refractory loss of about $10 \%$ of the melt mass would account for the increase of $\mathrm{Al}_{2} \mathrm{O}_{3}$, as well as provide additional chromium in the slag. The reason for the apparent loss of $\mathrm{CaO}$ is not understood at this time.

The chromium and zine were almost totally contained in the crystalline phase. The zinc (oxide) was found in the small, spinel-group crystals and in the dendrite crystals which were probably orthosilicates. The chromium was found as oxide in the blocky crystals, as a chromite in the spinel crystals, and also in the orthosilicate dendrites. The alkalis ( $\mathrm{Na}$ \& $\mathrm{K}$ ) were mainly in the (aluminosilicate) glass phase, with some in the orthosilicates. The alkali earths (Ca \& $\mathrm{Mg}$ ) were in the glass, orthosilicate, and spinel phases, with the $\mathrm{Mg}$ preferring the spinel. 


\section{REFERENCES}

1. C. R. Edinborough, Processing Criteria for TRU Removal From RWMC Stored Waste, ERDP 2802, EG\&G Idal..), Inc., August 1990).

2. J. L. Mayberry, W. J. Quapp, F. Fcizollahi, J. C. Del Signore, and J. McFee, Preliminary Systems Design Study Assessment Report, Vol. I-VIII, EGG-WTD-9594, June 1991.

3. D. Rotman, "Superfund Cleanup - The Burning Question," Industrial Chemist, January 1988, pp. 22-27.

4. Thermal Processes Evaluation for RWMC Wastes, EGG-WTD-9449, January 1991, pp. $42-\mathrm{A} 45$.

5. L. J. Staley, "Hazardous Waste Decontamination With Plasma Reactors," Hazardous Materials Control, Vol. 3, No. 2, March/April 1990.

6. S. L. Camacho, The F1 Manual: Application of Plasma Technology, Plasma Energy Corporation, Raleigh, NC, (1988).

7. S. L. Camacho, "Handbook of Applied Thermal Systems," Plasma Heating, McGraw-Hill 1988.

8. S. L. Camacho, "Industrial-Worthy Plasma Torches: State-of-the-Art," Pure and Applied Chemistry, Vol. 60), No. 5, 1988, pp. 619-632.

9. D. R. MacRac, "Application of Plasma Technology to Ferroalloy Processing," Plasma Technology in Metallurgical Processing, J. Feinman, ed., Iron and Steel Socicty, Warrendale, PA, 1987, pp. 149-57.

10. Ibid., "Applications of Plasma Technology to Steclplant Waste Treatment," pp. 125-130.

11. T. G. Barton, "Mobile Plasma Pyrolysis," Hazardous Waste, Vol. 1(2), 1984, pp. 237-247.

12. J. Krieger, "Plasma Technology to Tackle Toxic Wastes," Chemical and Enginecring News, December 20, 1980, pp. 22-21.

13. J. E. Goodwill, Proceedings of the First International EPRI Plasma Symposium, CMP Report No. 9()-9, May 1990, Chapters 11, 13, 14, and 16.

14. Proceedings of the First INEL Plasma Applications to Waste Treatment Workshop, Sponsored by the Idaho National Engineering Laboratory, EG\&G Idaho, Inc., Waste Management Division, Idaho Falls, Idaho, January 16-17, 1991.

15. A. D. Donaldson, R. P. Apa, T. L. Eddy, and J. E. Flinn, "A Review of Plasma Destruction of Hazardous Mixed Wastes," K. Etemadi and J. Mostaghimi, eds., Heat Transfer in Thermal Plasma Processing," HTD-Vol. 161, pp. 41-51, 1991, Etemadi, Ed., Minneapolis, MN, July $28-31,1991$, pp. $41-51$. 
16. EPA, Consent Order and Compliance Agreement 1085-10-07-30)8, in the matter of: United States Environmental Protection Agency and United States Department of Energy, Idaho National Engineering Laboratory, ID4890(0)8952, proceeding under Section 300 8(h) of Resource Conservation and Recovery Act, 42 usc, Section 6928(h), July 1987.

17. R. C. Bartholomay, Mineralogical Correlation of Surficial Sediment from Area Drainages, with Selected Sedimentary Interbeds at the Idaho National Engineering Laboratory, U.S. Geological Survey Water Resources Investigations Report 90-4147, August 1990.

18. S. M. Burns, S. N. Stanisich, M. J. Spry, and D. S. Shoop, Closure Plan for the Test Reactor Area Chemical Waste Pond (COCA Unit TRA-06), EGG-WM-9193, October 1990.

19. S. L. Pickett, and S. N. Stanisich, Closure Plan for the Test Reactor Area Paint Shop Ditch (COCA Unit TRA-(02), EGG-WM-9212, November 1990.

20. Retech Engineering, Ukia, CA.

21. Model PT-15() Nontransferred Plasma Torch, Plasma Energy Corporation, Raleigh, NC 27612.

22. J. L. Buclt et al., In Situ Vitrification of Transuranic Wastc: An Updated Systems Evaluation and Applications Assessment, Pub. No. PNL-480) Suppl. 1 UC-70), Pacific Northwest Laboratory, Richland, WA, March, 1987.

23. Controls for Environmental Pollution, Inc., P.O. Box 5351, Santa Fe, NM 87502.

24. J. E. Flinn et al., Annual Report on the TRU Waste Form Studies with Special Reference to Iron-Enriched Basalt, EGG-FM-5366, June 1981.

25. T. L. Eddy, P. C. Kong, D. V. Milcy, A. W. Erickson, and V. L. Smith-Wacherlic, Summary of the First Test Series Results, in preparation, December 1991. 

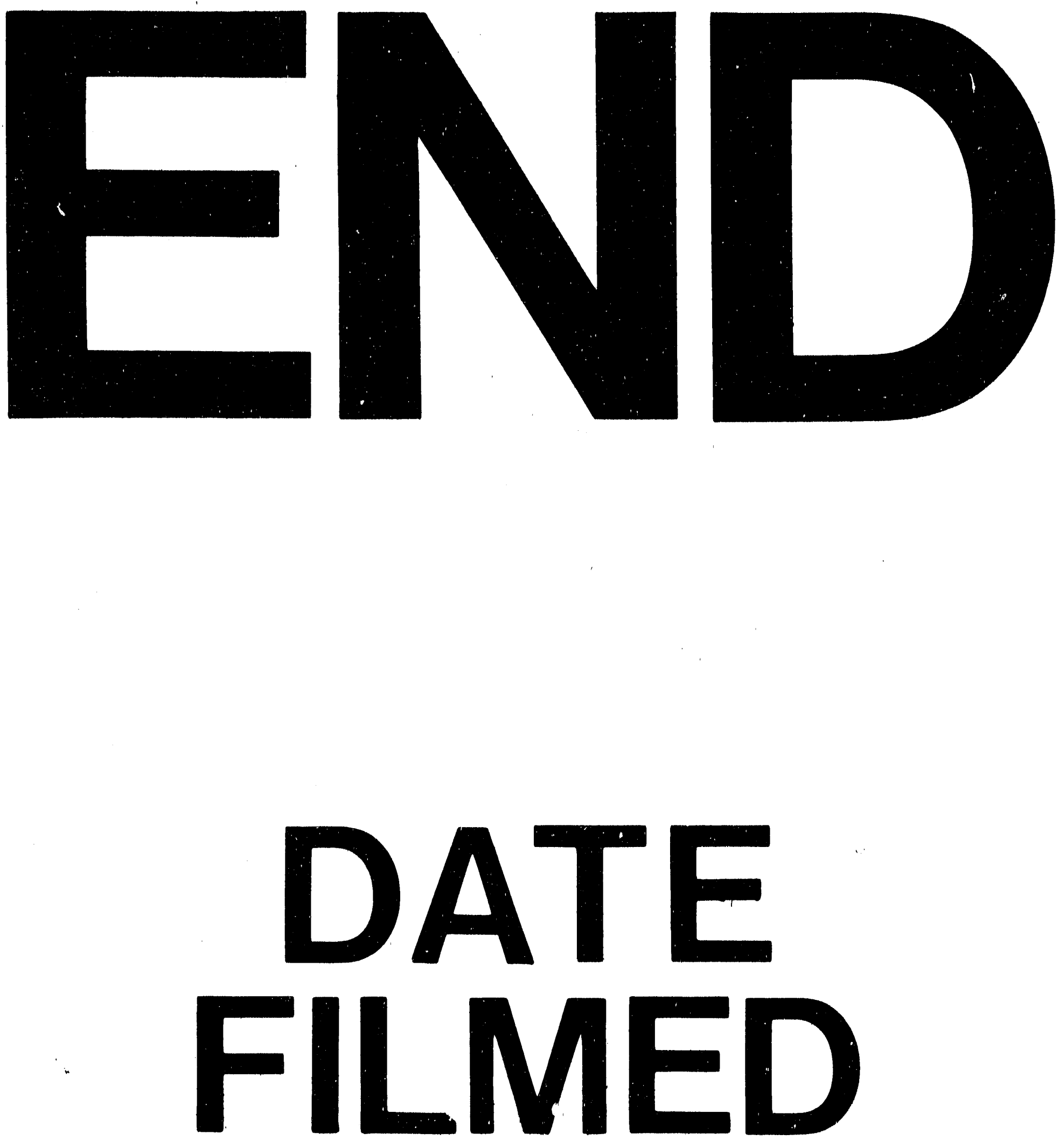

I

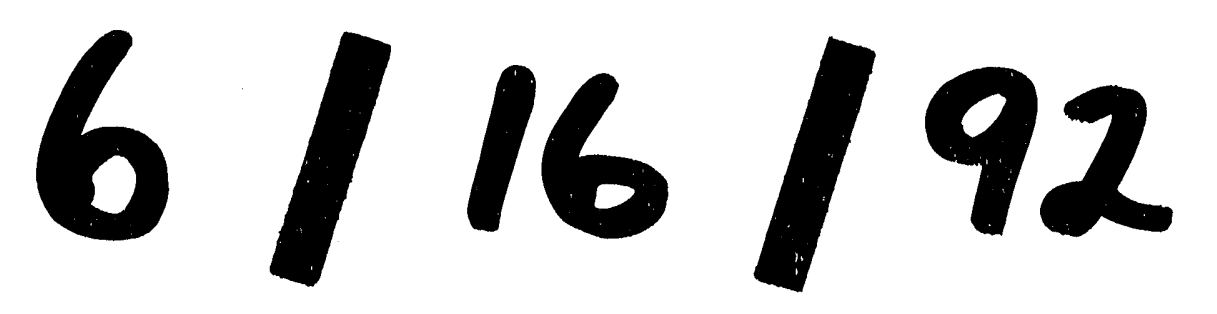


